\title{
$\mathbb{1}$ ) Nordic Council of Ministers
}

Arctic Business Analysis:

Creative and Cultural Industries

(4) 


\section{Arctic Business Analysis}

Creative and Cultural Industries

\section{ANP 2018:708}

ISBN 978-92-893-5343-4 (PRINT)

ISBN 978-92-893-5344-1 (PDF)

ISBN 978-92-893-5345-8 (EPUB)

http://dx.doi.org/10.6027/ANP2018-708

(c) Nordic Council of Ministers 2018

Layout: Bjørn Ortmann

Cover Photo: Mads Pihl / Visit Greenland

Print: Rosendahls

Printed in Denmark

\section{Nordic co-operation}

Nordic co-operation is one of the world's most extensive forms of regional collaboration, involving Denmark, Finland, Iceland, Norway, Sweden, the Faroe Islands, Greenland, and Åland.

Nordic co-operation has firm traditions in politics, the economy, and culture. It plays an important role in European and international collaboration, and aims at creating a strong Nordic community in a strong Europe.

Nordic co-operation seeks to safeguard Nordic and regional interests and principles in the global community. Shared Nordic values help the region solidify its position as one of the world's most innovative and competitive.

\section{Nordic Council of Ministers}

Nordens Hus

Ved Stranden 18

DK-1061 København K

www.norden.org

Download Nordic publications at www.norden.org/nordpub 


\section{Arctic Business Analysis}

Creative and

Cultural Industries

(9)

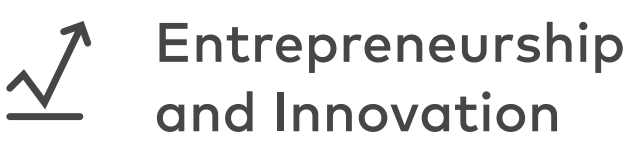

(4) Creative and
Cultural Industries

\} PPPs and Business Cooperation

D Bioeconomy 


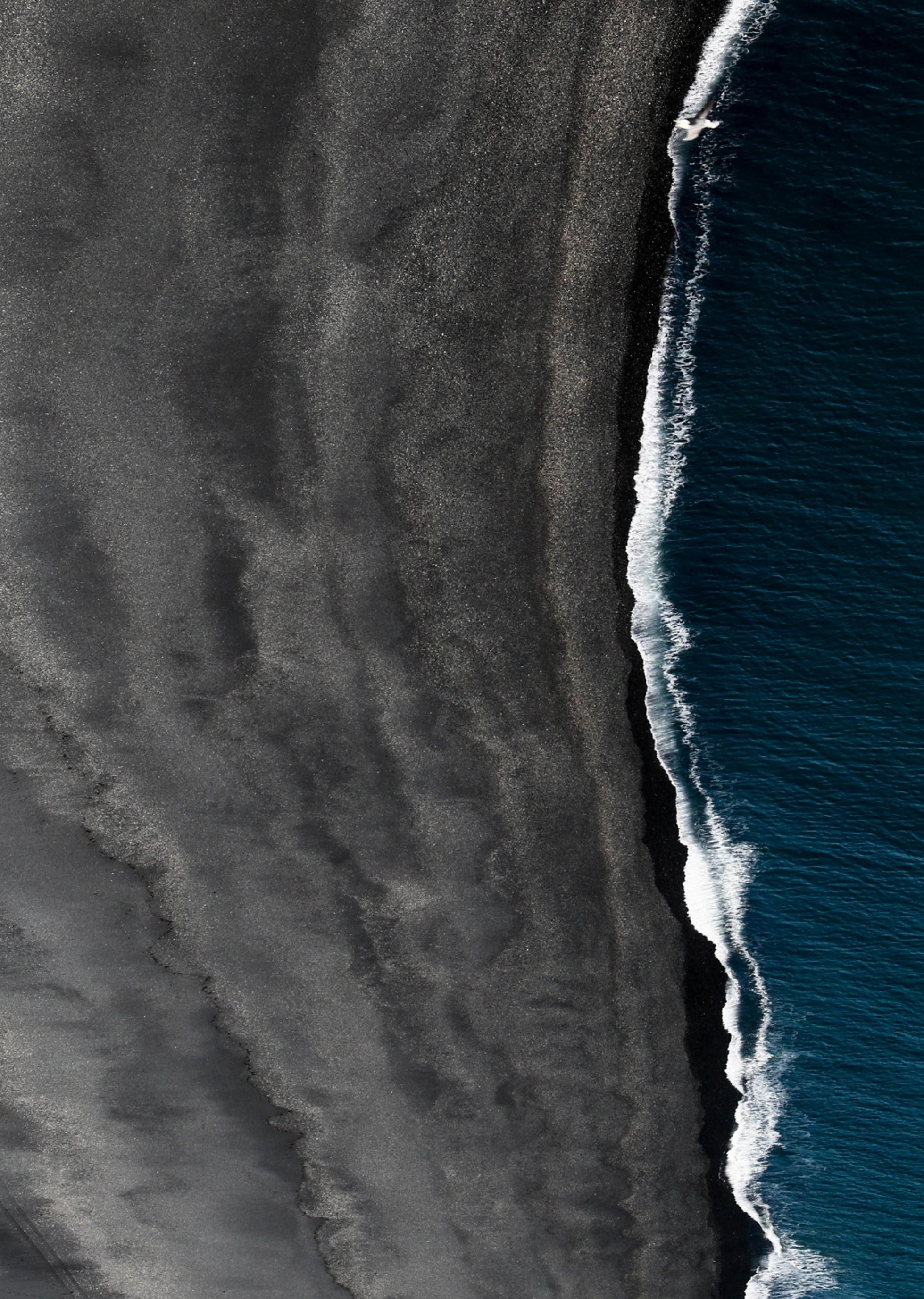




\section{CONTENTS}

1. Introduction

2. Background

3. Executive Summary of the Arctic Business

Analysis

4. The Nordic Arctic Business Environment:

Creative and Cultural Industries

4.1 Mapping of economic activities and policies

4.2

Drivers and enablers of business

development

4.3

Recommendations

5. Cross-cutting issue across the Arctic Business

Analysis

51

6. Methodology

Bibliography

Endnotes 
The Arctic region is increasingly attracting economic and political interest. New business opportunities are on the rise and Arctic stakeholders are playing a key role in facilitating and creating favourable conditions for boosting Arctic economic activity. There is currently a wide spectrum of business activities, of which oil and gas, mining, and shipping are well known. Nonetheless, the Arctic region holds great economic potential to be realised in other areas such as the (blue) bioeconomy, tourism, innovation and entrepreneurship, and indigenous cultural businesses through business activities and policies designed to address specific opportunities and needs of the region.

Business development in the Nordic Arctic must be rooted in its people(s) and have a drive to create innovative development, in which the Arctic's unique resources and human capital become competitive on a global scale. Urbanisation has especially highlighted the necessity of Arctic business development. Rural Arctic communities are under pressure, as younger generations want services, opportunities, and education offered in greater metropolitan areas. Arctic business development is therefore an existential issue because creating economic hubs of a sufficient size and critical mass would offer younger generations the quality of life they desire. In response, new technologies are revising the concept of "remote" and are rendering previously inaccessible projects economically feasible. Moreover, new technologies in transport, communication, raw material processing etc. are disrupting traditional business models and forcing business to innovate and to reinvent themselves.

The Nordic Arctic countries (through the Nordic Council of Ministers) 
of sustainable economic development in the Arctic as the logical next step in the work in and for the Arctic. Sustainable development focuses on a balance between economic, social, and ecological dimensions, and aims to ensure that the needs of the present generation are met without compromising future generations' ability to meet their own needs. ${ }^{1}$ As such, promoting sustainable economic development in the Nordic Arctic requires an understanding of the region's business environment and policy incentives, as well as the identification of opportunities for unlocking the Nordic Arctic economic potential, and the development of practical enablers to achieve this end - to the benefit of the entire Arctic. With this perspective in mind, the Nordic Council of Ministers, in collaboration with the Arctic Economic Council, has commissioned the consortium of Voluntas Advisory and the Confederation of Danish Industry (DI) to conduct this Arctic Business Analysis.

The Arctic Business Analysis covers the areas of Entrepreneurship and Innovation, Public-Private Partnerships (PPPs) and Business Co-operation, Bioeconomy, and Creative and Cultural Industries. Each area is covered in a separate publication. This report presents the findings for PPPs and Business Co-operation. The executive summary presents the findings across the four areas of the Arctic Business Analysis.

\section{Nordic Council of Ministers}

The Arctic Business Analysis revolves around opportunities to promote sustainable economic development within the Nordic co-operation, specifically the Nordic Council of Ministers (NCM), as well as other Nordic Arctic stakeholders. It is therefore important to understand NCM's Arctic priorities and its organisational structure.

NCM is the official body for Nordic intergovernmental co-operation. The overall responsibility for this co-operation officially lies with the Nordic Prime Ministers. In practice, the Ministers for Nordic Co-operation, on behalf of the Prime Ministers, assume responsibility for the co-ordination of inter-governmental co-operation. Besides the Ministers for Nordic Co-operation, NCM consists of 10 ministerial councils (MRs) that cover different sectors and are supported by 16 committees of senior officials (EK). The work in the Minister Councils are handled within the Nordic Council of Ministers' Secretariat with a Secretary General responsible for the day-to-day operations of the intergovernmental co-operation and its 12 Nordic institutions and 3 Baltic offices.

NCM has since 1996 had an Arctic co-operation programme. A new Arctic co-operation programme, "Nordic Partnerships for the Arctic" for 2018-2021 will enter into force by 1 January 2018. The overall aim is to promote sustainable development in the Arctic with regards to the four themes of 1 ) peoples; 2 ) planet; 3 ) prosperity; and 4) partner- 


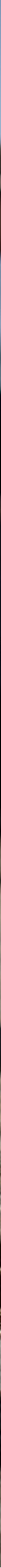


In 2016 the Nordic Co-operation Minister (MR-SAM) decided to increase efforts supporting economic development in the Arctic. It was acknowledged that there needs to be more knowledge on the types of actions the Nordic countries and the Nordic Co-operation within the auspices of the Nordic Council of Ministers (NCM) could take. This led to the making of the "Arctic Business Analysis".

The overarching aim of the Arctic Business Analysis is 1) to provide a better understanding of the Nordic Arctic business environment as part of promoting a greater focus on enablers and drivers of sustainable economic activities in the Nordic Arctic and 2) to generate practical recommendations on how the Nordic Co-operation can promote economic activities in the Nordic Arctic through the establishment of a data foundation upon which to draw fact-based conclusions. The findings of the analysis will feed into NCM's Arctic Co-operation Programme in which sustainable economic development is a key theme. Specifically, the analysis will contribute to NCM's focus on economic development and investments in the Arctic - a political priority for the Nordic Co-operation.

In addition to outlining enablers and best practices that can promote sustainable economic activities on behalf of the Arctic population, the analysis is also aimed at contributing to NCM's work with the United Nations Sustainable Development Goals (SDGs). Overall, the analysis will contribute to sustained, inclusive, and sustainable economic growth (SDG 8) in the Nordic Arctic, and an inclusive and sustainable industrialisation and promotion of innovation (SDG 9). Moreover, it will analyse sustainable economic activities related to bioeconomy,

$\leftarrow$ A young girl at Qasigiannuit Museum in Greenland. Photo: Mads Pihl / Visit Greenland creative and cultural industries, and business co-operation, which would promote affordable and clean energy (SDG 7), sustainable cities and communities (SDG 11), and life below water and on land (SDG 14 \& 15) among others. 

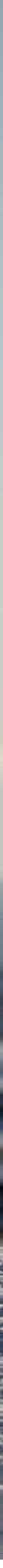
rience, and supervise local governments and municipalities looking to engage in a PPP.

Business co-operation in the form of clusters in the Arctic are generally few, undeveloped, and still need to secure financing long-term, though local variations exists. Norway is a leading figure in supporting national cluster development through initiatives like Innovation Norway. Public support and increased cross-border co-operation are some of the drivers that will benefit cluster development in the Nordic Arctic. Public funding should ensure that business clusters can be created and developed while also ensuring a secure exit strategy so the clusters become financially sustainable. Furthermore, clusters can support their members and develop a greater market reach by co-operating across borders, as well as branding the region as a place for doing business.

Bioeconomy integrates a number of solutions for a sustainable future, both environmentally, socially, and economically. Bioeconomy is already an important economic segment in the Nordic Arctic, constituting $10 \%$ of the overall Nordic economy and moving towards $20 \%$ in some countries. Increasing the innovative use of biomass resources from land and sea presents a key opportunity to simultaneously ensure environmental sustainability and economic growth. Bioeconomy development should focus on increasing the value of products derived from biomass, and increasing the uses of side streams created by bioeconomy activities. These include practices such as the use of fish sidestreams for pharmaceutical products, wood residues in textile production or fish feed, etc. If bioeconomy in the Arctic is to be harvested, synergies between companies and industries must be built in both public and private sectors as well as across sectors and borders to facilitate the right public support and incentives to drive bioeconomy innovation, commercialisation and growth. Furthermore, the future bioeconomy requires substantial creative capabilities. Rebranding bioeconomy accordingly has the potential to attract a younger generation to an industry perceived as very traditional. As many bioeconomy activities are located in rural areas, developing bioeconomy also counters urbanisation, and promotes rural development and employment in the Nordic Arctic.

The Nordic Arctic creative and cultural industries of film, tourism, and indigenous cultural businesses are becoming increasingly important platforms through which the Nordic Arctic countries can create value and growth - economically, socially, and culturally. Despite significant variations in size and development, Nordic Arctic film industries are gaining considerable traction across the entire Nordic Arctic region. Policy support such as public funding and production rebates have been instrumental to the success of film industries, but ensuring long-term development requires knowledge sharing and collaboration in developing film production skills e.g. through official training across the Nordic Arctic. Nordic Arctic tourism has grown steadily in the last 
$\downarrow \quad$ Arctic Winter Games athletes having fun in the urban spaces of Nuuuk in Greenland.

Photo: Mads Pihl / Visit Greenland decade. Public support, public-private collaborations, and transnational collaborations have been key in developing Arctic tourism. Transnational collaboration shows great potential, as Arctic regions, especially those in Finland, Norway, and Sweden, are generally perceived as one destination by the tourism market. Growth in Sami and Inuit indigenous businesses offer an opportunity for economic growth whilst integrating Arctic indigenous peoples into the regional and international economy. Business opportunities include indigenous tourism, film, and other cultural activities. However, it is important to ensure that Nordic Arctic Indigenous peoples' culture, life, and creative work are promoted and not misrepresented when developing these areas.

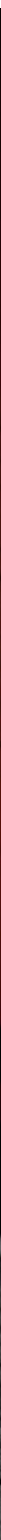




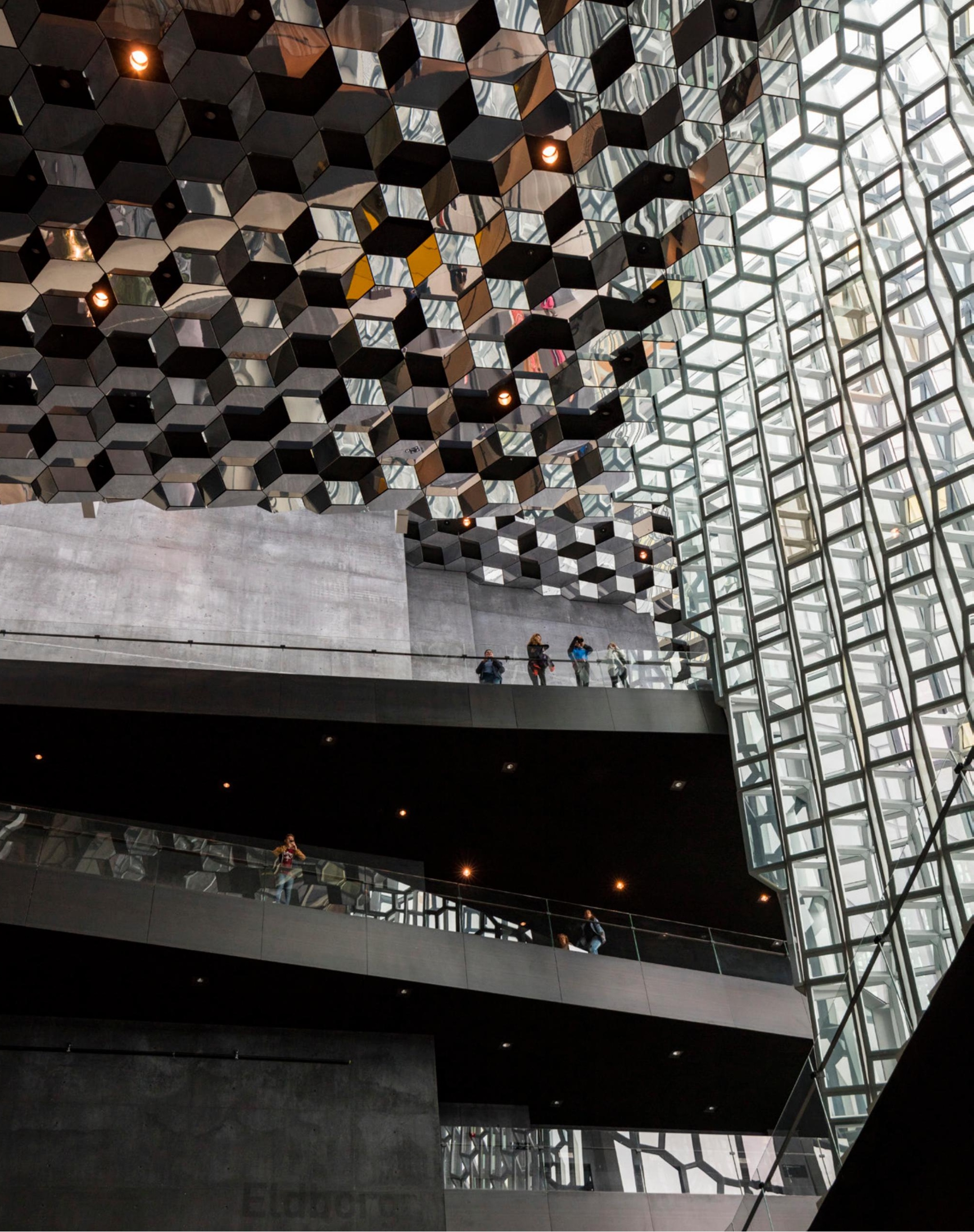




\section{THE NORDIC \\ ARCTIC BUSINESS \\ ENVIRONMENT: \\ CREATIVE \\ AND CULTURAL \\ INDUSTRIES}

Creative and Cultural industries are becoming an increasingly important platform through which the Nordic Arctic countries can create value and economic growth. This section will outline key policy support mechanisms and economic activity in the Nordic Arctic creative and cultural industries, which in this study cover the film industry, tourism industry, and businesses related to indigenous culture, as well as present some of the key drivers and enablers of business development in these areas. It is important to note that although tourism is often not considered a creative and cultural industry, the industry is closely related to Nordic Arctic culture and the promotion of it. Tourism exposes visitors to Nordic Arctic culture, either through experiences or creative and cultural commodities or products, which in turn provide new sources of income. 


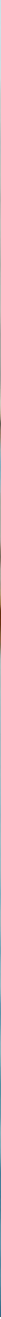




\title{
4.1 MAPPING OF ECONOMIC ACTIVITIES AND POLICIES
}

\author{
FILM
}

Even though the film industry may not be the most productive source of economic growth, the industry's indirect effects, such as employment, regional development, personal development, education, and social inclusion, are vital. ${ }^{2}$ For example, in Iceland $20.1 \%$ of tourists mention film as one of the main reasons for visiting Iceland. ${ }^{3}$ As such, the value of a strong film industry goes beyond standard measures of benefit. Filming and production tasks contribute to new and more diversified employment activities, regional attractiveness, and stronger regional identities. The film industry is present in all the Nordic Arctic countries to varying degrees.

Iceland is arguably home to the most developed film industry in the Nordic Arctic. Numerous high-profile Hollywood blockbuster projects have already visited the island and many more are set to film in the future. In 2014 the industry reached a production value of over EUR 107.7 million. ${ }^{4}$ The key policy mechanism to support film in Iceland is a reimbursement from the state treasury of $25 \%$ of the costs incurred by production of films and television programmes made in Iceland. Norway and Finland have also implemented a $25 \%$ reimbursement of costs of

$\leftarrow \quad$ Videographer Aningaaq Rosing Carlsen filming in Nuuk in Greenland. Photo: Visit Greenland producing films in the country. The success of such support is illustrated by Norway's growing film industry, which reached a size of EUR 6 million in 2012. ${ }^{5}$ The Swedish film industry shares many similarities to that of
SUMMARY: Despite significant variations in size and development, film industries are gaining considerable traction across the entire Nordic Arctic region. Policy support has been instrumental to the success of Nordic Arctic film industries, where primary support mechanisms include production rebates, public funding, and training services. Most notable is the Icelandic film industry. Iceland's dramatic landscapes, experienced production companies, and $25 \%$ cash rebate on production costs of filming in the country serve as foundations to which film-makers from all over the world are attracted. 


\begin{tabular}{|c|c|c|c|c|c|c|}
\hline & SWE & NOR & FIN & ISL & FRO & GRL \\
\hline Cinema Screens & 808 & 434 & $311^{a}$ & $40^{\circ}$ & $3^{a}$ & $3^{a}$ \\
\hline Domestic film releases (year) & 46 & 23 & $40^{a}$ & 8 & NA & $1^{\mathrm{a}}$ \\
\hline Admissions per capita (year) & 1.8 & 2 & 1.6 & 4.2 & 1.5 & NA \\
\hline Employment in cultural industries & $4.1 \%$ & $3.3 \%$ & $4.0 \%$ & $5.1 \%$ & $2 \%$ & NA \\
\hline
\end{tabular}

(share of total employment)

the abovementioned countries, but does not have a product reimbursement incentive. The main mechanism of support is public funding, with a few central focal areas. These include production and distribution funding, film schools, and regional funding, as well as the support of overseas festivals. Sami film is also gaining traction, with initiatives like the Sami Film institute in Norway and a film festival in Finland.

The Greenlandic and Faroese film industries are very small, but growth is on the horizon. In Greenland, it is estimated that about 50 people ( $0.09 \%$ of the population) are working professionally in film and TV production. The Government of Greenland provides subsidies that amount to EUR 387,615 on a yearly basis from 2016 onwards. Furthermore, film makers can seek support from other cultural subsidies, such as the culture funds of the government, cultural work scholarships, as well as local and regional foundations. The Faroese film industry is also at an early stage of development, but Faroese culture and media policy show promising signs of growth. ${ }^{6}$ For example, funding for the establishment of a film industry has more than doubled from 2015 to 2016. In 2017, the Faroese government has allocated subsidies for the establishment of a Faroese film house that will be responsible for the administration of funds, consultation, coordination of the industry, and increasing the Faroe Islands prominence as a film country abroad. Despite their links to Denmark, Greenland and the Faroe Islands are unable to apply for production support from the Danish Film Institute due to culture clauses for both countries, and hence production funding is very limited. To help develop their respective film industries, Greenland and Faroe Islands have entered into collaboration with Iceland called North Atlantic Talents. The purpose of this project is to strengthen the North Atlantic production of film and storytelling for moving images through a close collaboration in talent development initiatives for both professionals and aspiring filmmakers. ${ }^{7}$ Aside from building competen- $\uparrow \quad$ Source: Calculations based on data from National Bureaus of statistics and National Film Agencies/Funds/Institutions (2015 data)

a Stakeholder information 
$\downarrow \quad$ Note: Based on a qualitative assessment of data on the level of support and economic activity for each country cies and incubating more film workers in the practical field, the film industries in Greenland and the Faroe Islands are both in need of institutions that work professionally with politicians and decision makers to create stronger structural frameworks for film production. For instance, a dedicated effort in the Faroe Islands and in Greenland would stand a good chance of convincing local politicians to set up tax reimbursement schemes - similar to the tax rebate scheme in Iceland - which could be established independently from Denmark's lawmakers who have previously been uninterested in the Danish film industry's efforts. The industries in Greenland and the Faroe Islands have close ties with politicians and decision makers, but up until now, work on a structural and foundational level has been carried out on a volunteer basis by local organisations. On the Faroe Islands however, the upcoming film house is due to take over, and Greenland is in the process of establishing similar, smaller scale institutions, such as a local film workshop facility and possibly a Greenlandic film institute.

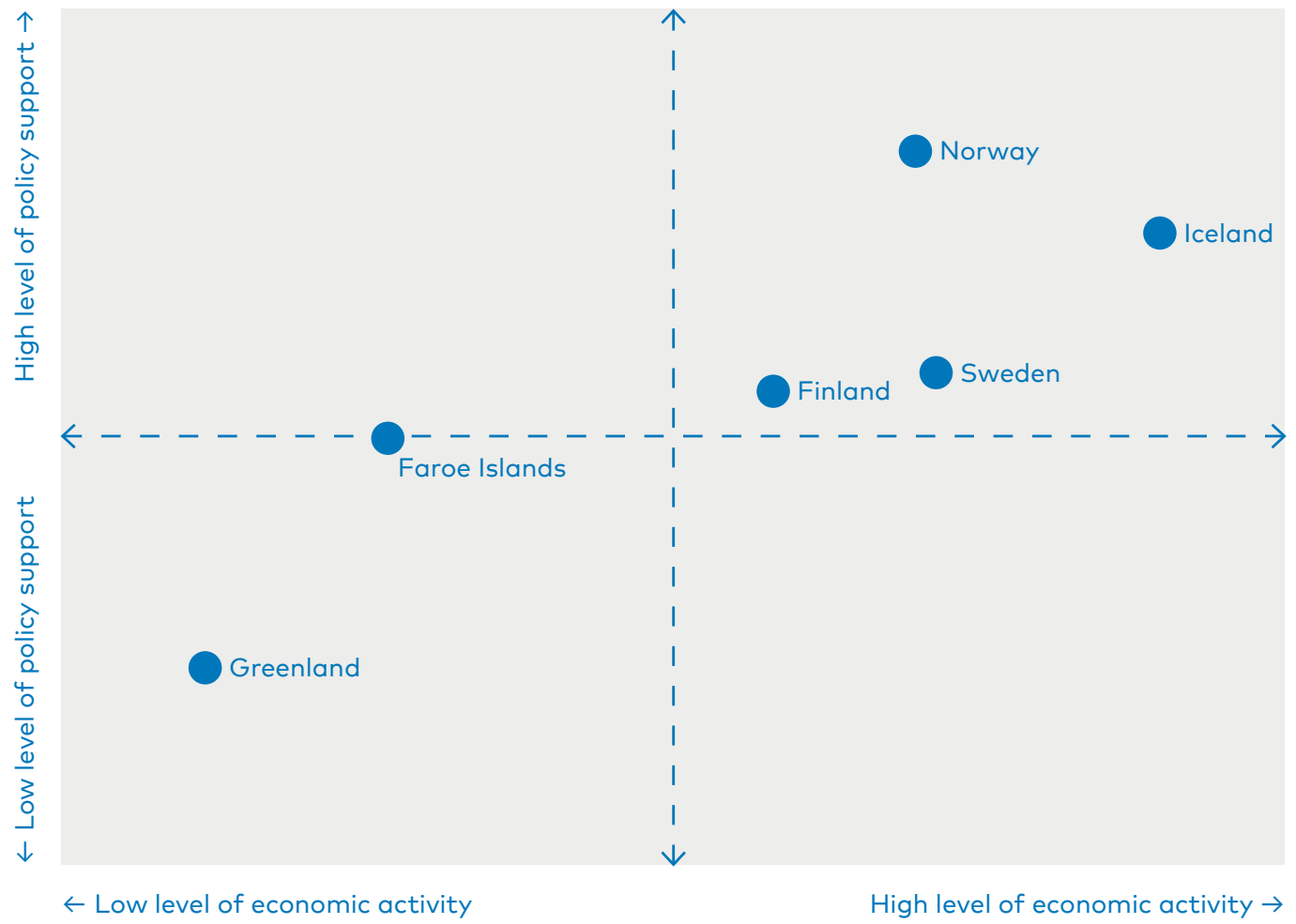




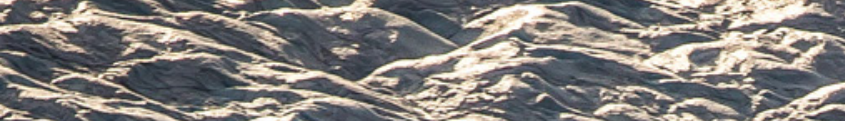

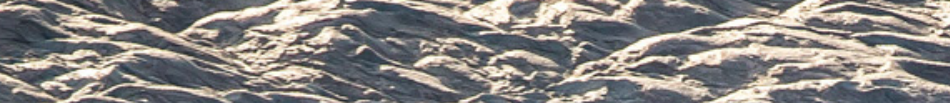

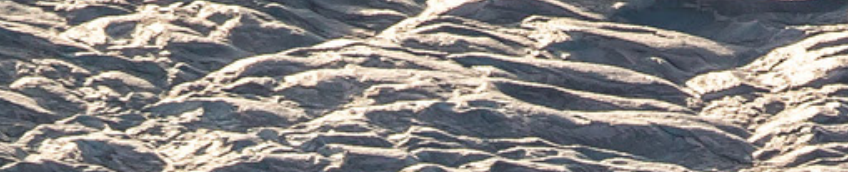

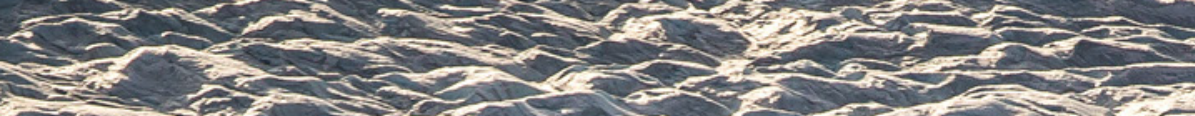
rsin 15

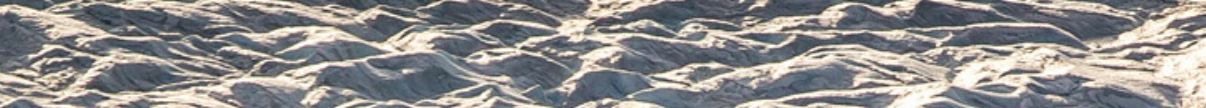

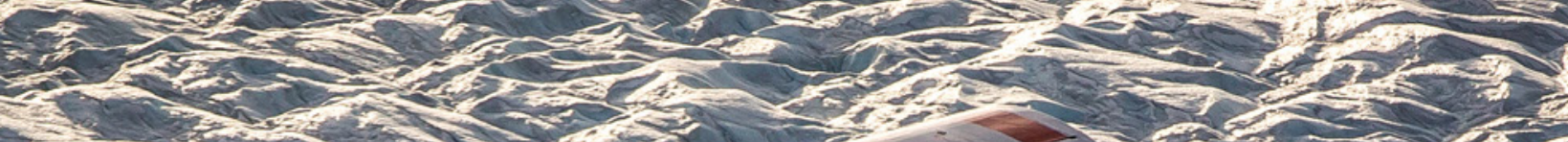

\section{2}

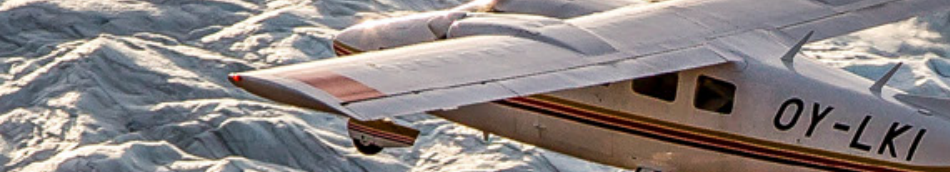

$$
\text { - } 01-k+2
$$

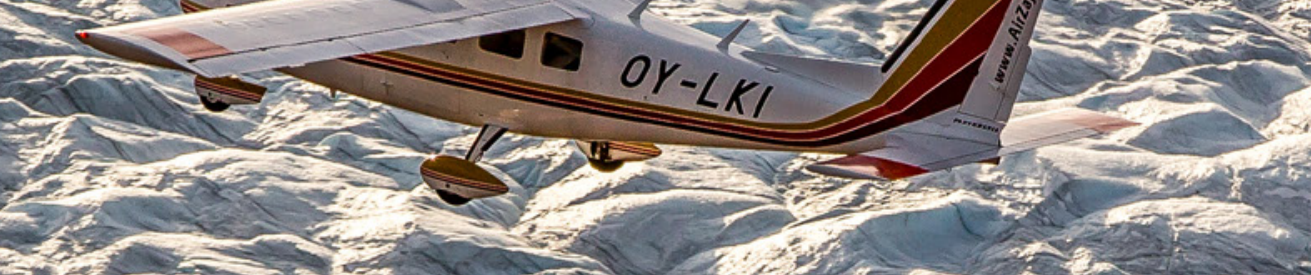

sesicis

T.

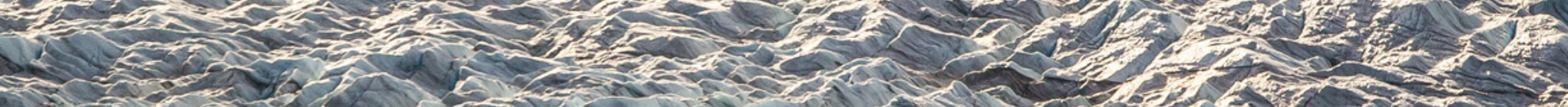

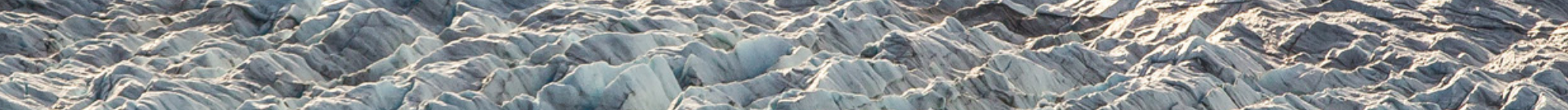

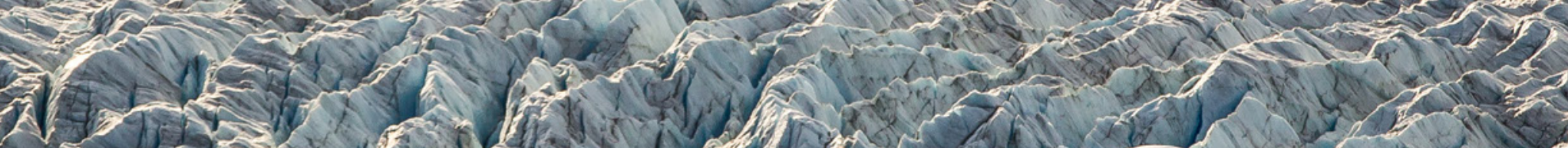
1. 3 ( - -2.0 (1)

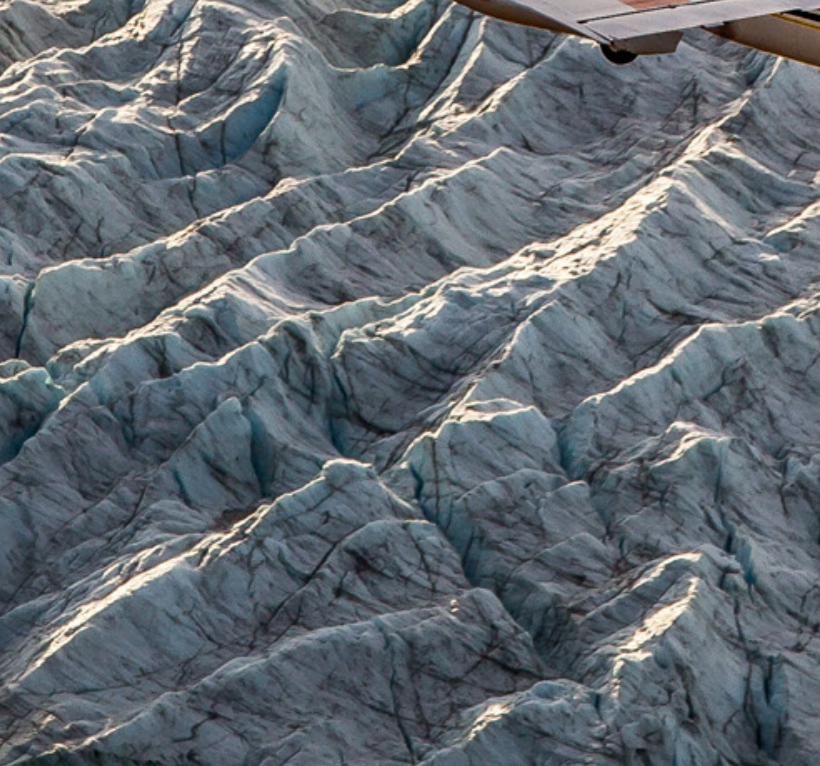

217

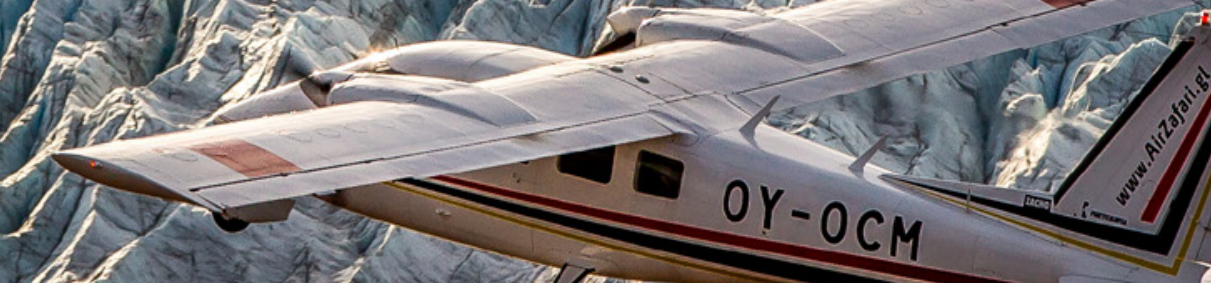
. (2) 1 जि

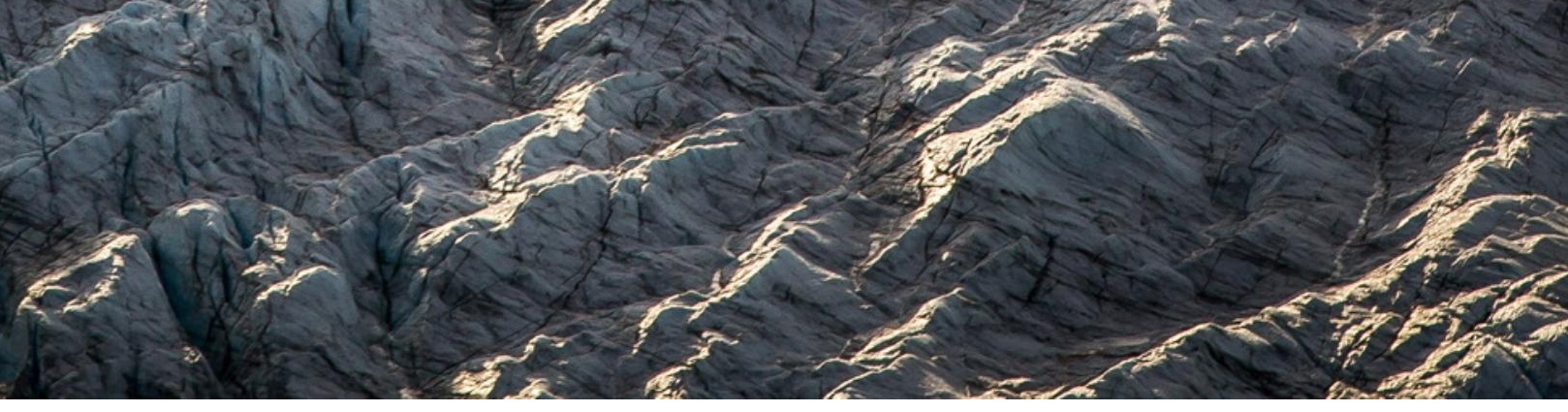




\section{TOURISM}

Tourism has become increasingly highlighted in Nordic Arctic policy as an opportunity for economic growth and promotion of Arctic culture be it arts, music, nature, or indigenous cultures. Correspondingly, Arctic tourism can be defined as tourism based in high-latitude environments characterised by cold and extreme nature, involving nature-based, culture-based and sports-based activities.

In Iceland, the tourism industry has established itself as the third pillar of the Icelandic economy and is one of Iceland's fastest growing sectors. In 2016, the tourism industry accounted for approximately $39.2 \%$ of all export goods and services. Iceland enjoys one of the highest per capita tourist ratios in the world, with about 5 tourists per inhabitant. ${ }^{8}$ The Icelandic tourism industry operates under the overarching Tourism Administration Act. ${ }^{9}$ The purpose of this Act is to promote the development of tourism as an economic sector through mechanisms such as marketing and promotional funding. Contributing to the growth in Icelandic tourism is a combination of the financial crisis in 2007-08, which led to a devaluation of the Icelandic currency, a volcanic eruption catching global attention, and global trends in the cost of travel, which

$\leftarrow \quad$ Two Air Zafari flightseeing planes over the Greenland Ice Sheet near Kangerlussuaq Airport.

Photo: Mads Pihl / Visit

Greenland made Iceland more accessible for tourists. However, the rapid growth in tourism in Iceland has brought with it a considerable backlash. Limited planning and the fact that investments have not followed suit with the growth in tourism have led to a number of problems. These include in-
SUMMARY: Nordic Arctic tourism has been growing steadily throughout the decade and is slowly becoming one of the most important industries within the region. Not only does tourism promote economic growth and employment, it contributes to the development of rural Arctic regions and the Arctic culture. Public support has proven important for the development of tourism activities and each Nordic Arctic country has established a national tourism board that aims to brand and market tourist activities, e.g. Visit Faroe Islands, Visit Greenland, Visit Norway. Transnational collaboration has also proven effective. For instance, the northern regions of Norway, Sweden, and Finland have combined their efforts to promote and develop Arctic tourism through Visit Arctic Europe, as tourists generally perceive these regions as one region. Iceland, Greenland, and the Faroe Islands also promote tourism jointly through the North Atlantic Tourist Association (NATA). 


\begin{tabular}{|c|c|c|c|c|c|c|}
\hline & SWE & NOR & FIN & ISL & FRO & GRL \\
\hline Tourism industries as share of GDP & $2.7 \%$ & $4.1 \%$ & $2.5 \%$ & $6.7 \%$ & $1.4 \%$ & NA \\
\hline $\begin{array}{l}\text { Employment in the tourism industries' } \\
\text { (share of total employment) }\end{array}$ & $3.8 \%$ & $6.7 \%$ & $6.2 \%$ & $5.1 \%$ & $1.6 \%$ & $10 \%$ \\
\hline
\end{tabular}

frastructure degradation, excessive numbers of tourists, and increased environmental fragility. Therefore, planning to avoid these issues and to ensure tourism that is both economically beneficial and sustainable without negatively affecting the local populations and environment is important.

Norway's tourism industry is also growing in economic importance. From 2013 to 2015, the production value of tourism increased from EUR 15.4 billion to EUR 16.8 billion. ${ }^{10}$ Tourism accounts for $4.2 \%$ of GDP, with 1 in 15 people working in tourism-related industries. In the northern regions of Norway, promotion of tourism is conducted through programs such as Winter Experiences in Northern Norway. Tourism is also becoming more important in the Finnish economy in recent years. In 2015, foreign tourists spent around EUR 4 billion in Finland and the overall industry employed around 140,000 people. The growth of the industry is guided by "Achieving more together," which is a government roadmap for growth and renewal in Finnish tourism between 20152025. In Lapland, tourism is promoted through the organisation House of Lapland who also collects data on the developments in regional tourism. For the purpose of growth, public subsidies are provided to growth-oriented and networked tourism enterprises with expanding international operations. ${ }^{11}$ Sweden's tourism industry is also experiencing considerable growth. Tourism consumption in Sweden increased by EUR 1.9 billion, which amounts to 7\% growth in 2015. More dramatically, the Swedish tourism industry has grown by EUR 13.7 billion (88\%) from 2000 to $2015 . .^{12}$ It is the Swedish Agency for Economic and Regional Growth (Tillvaxtverket) and the Swedish tourism organisation Visit Sweden who are responsible for developing tourism at the national level and marketing Sweden as a tourist destination internationally. ${ }^{13}$ Finally, to promote and increase tourism in the Arctic areas, the northern regions of Norway, Sweden and Finland have combined their efforts to promote and develop Arctic tourism through Visit Arctic Europe, as these regions are generally perceived as one destination in the tourism market.

The Faroe Islands and Greenland have also increasingly started to promote tourism activities. The Faroe Islands aim to double tourism $\uparrow \quad$ Source: Calculations based on data from EUROSTAT, National Bureaus of Statistics, and National Tourist Buraus (2015 data) 
Stegastein, Aurland, Norway. Photo: Rob Bye by 2020 in comparison to 2012 levels. As a part of this goal, the Faroe Island tourism board, Visit Faroe Islands, was reorganised and given greater funding for marketing abroad. Five years into fulfilling this goal, results are showing. For example, from the first half of 2014 to the same time in 2015 , overnight stays increased by $16 \% .{ }^{14}$ This was partly a result of the attention given to the total solar eclipse in 2015, which could be viewed from the Faroes. It was also a result of Faroe Island's heavy investment in media promotion and PR campaigns abroad, such as inviting 262 media personnel to visit the islands in 2016 . Visit Faroe Islands has also set up a network of 80 tourism ambassadors that seek to attract meetings, conferences, and events to the islands. ${ }^{15}$

Greenland's tourism industry is small, but growing. The years 2015 and 2016 showed growth in tourists arriving by air, with a $23.8 \%$ increase in 2015 and a $9.9 \%$ increase in $2016 .{ }^{16}$ Promotion of tourism is handled through the national tourism board, Visit Greenland. This includes the implementation of the Strategy 2016-2019, which intends to promote the industry through focused marketing and project development in such industries as cruise tourism. Moreover Iceland, Greenland, and the Faroe Islands have entered into a collaboration in 2006 for the purpose of promoting tourism in the north Atlantic. This occurs through NATA, the North Atlantic Tourist Association, which offers grants and support for projects that aim to promote co-operation in tourism. How-

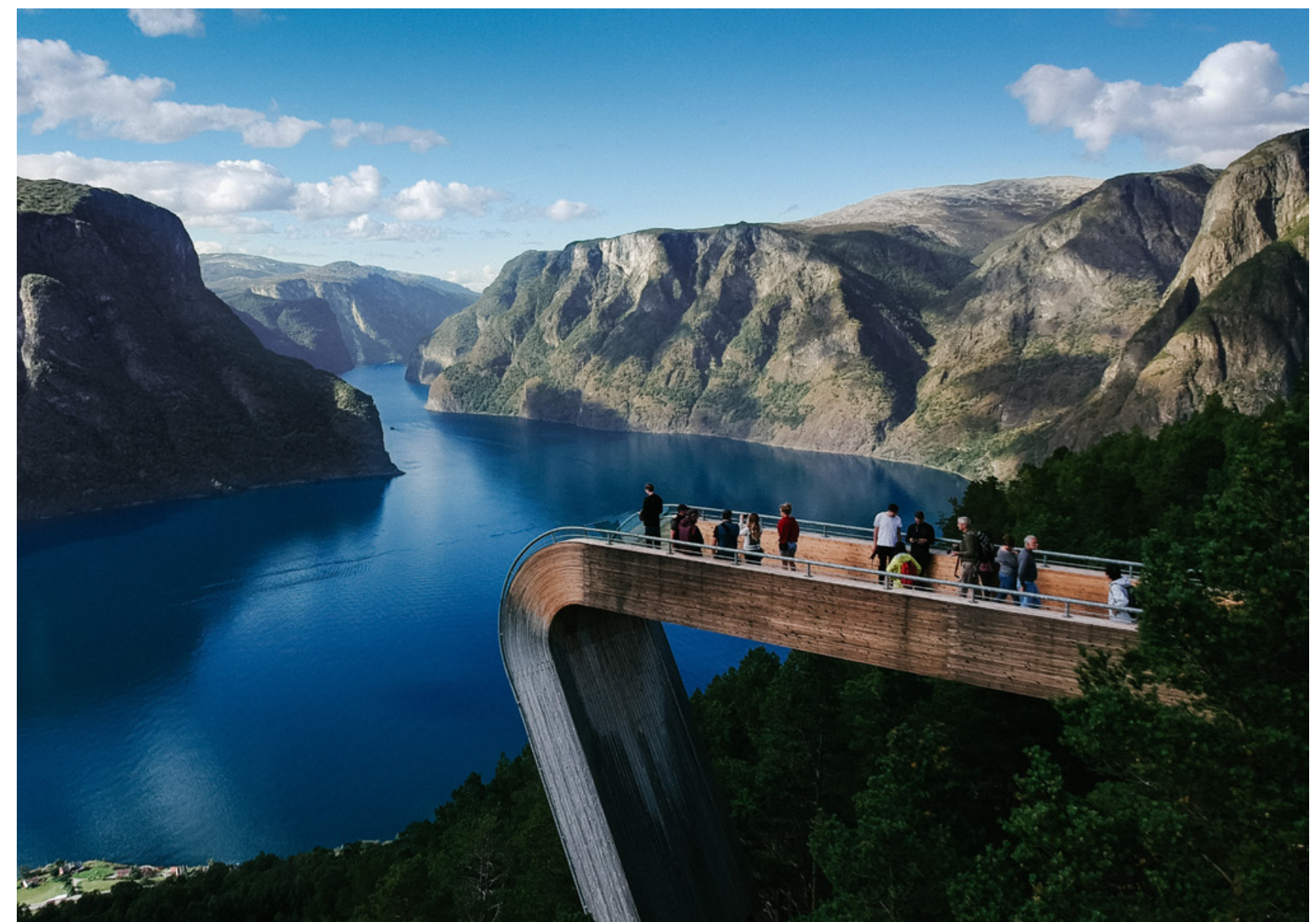


ever, there is a long road ahead for the Greenlandic tourist industry to tap into its full potential. ${ }^{17}$ Education, from simple training to official degrees, has the potential to strengthen innovation and sustainability within the sector. For example, formal training for park rangers and guides concerning Greenlandic nature and environment can help ensure sustainable tourism development in the future. Training may also help provide certification to local Greenlanders who can then provide tourism services. Entrepreneurial activities related to tourism in Greenland are also on the rise, as more and more actors can see large untapped potential in the industry. There are a lot of destinations with room to develop new and creative experience products. The question remains as to how entrepreneurship in tourism can be established in a more network-oriented way, so that experience, innovation, and attained knowledge can be shared. This requires a greater focus on collaboration across the Greenlandic tourism industry. Such collaboration also has to reach into the common understanding of the future administration of roles, responsibilities and organisational structures.

$\downarrow \quad$ Note: Based on a qualitative assessment of data on the level of support and economic activity for each country

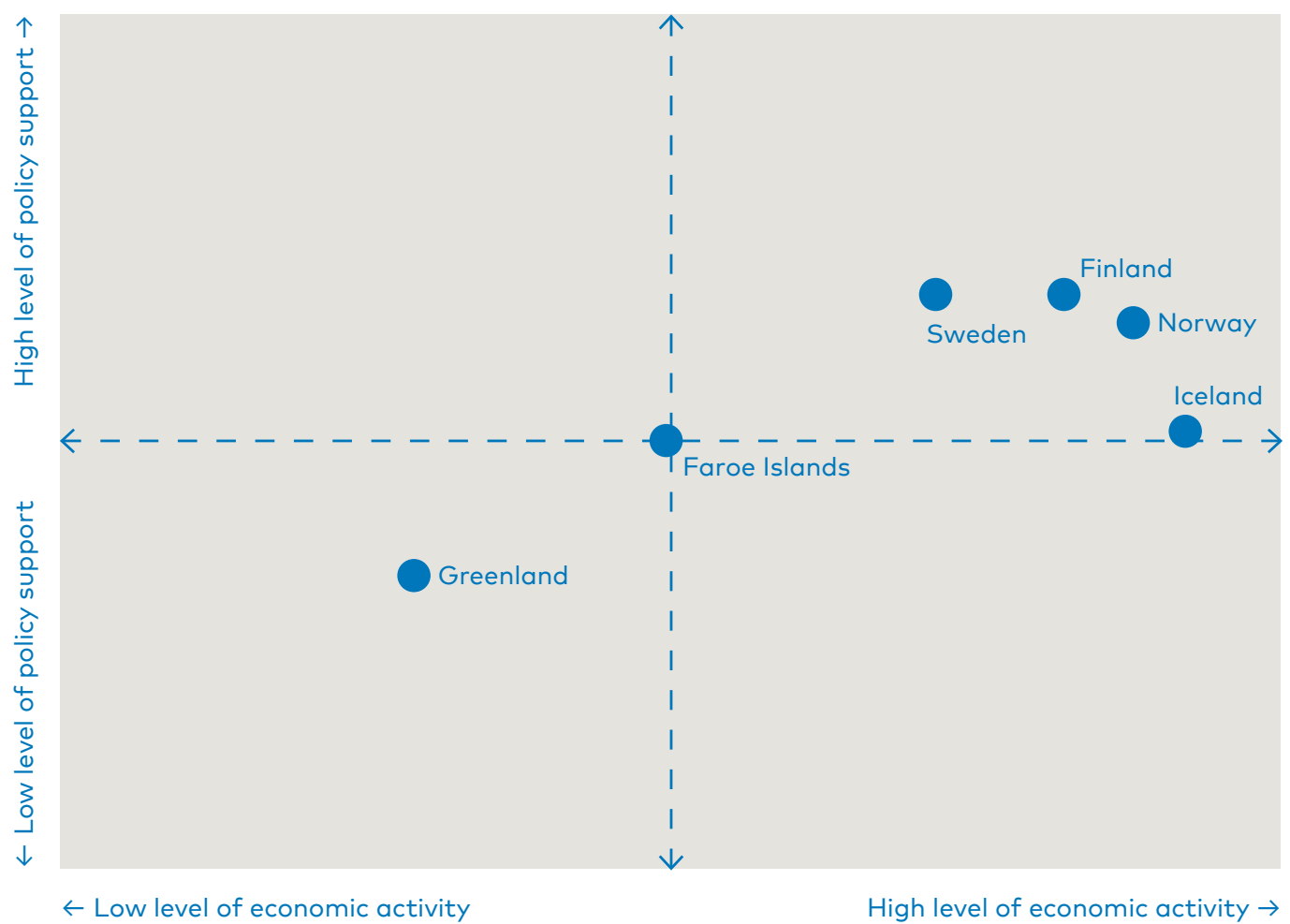




\section{INDIGENOUS BUSINESS}

The indigenous populations in the Nordic Arctic include the Sami population in northern Finland, Norway, and Sweden, and the Invit population in Greenland. The Sami are the only designated indigenous people in the European Union, and its population is spread across four regions with approximately $80,000-100,000$ people in total. This includes about 20,000-40,000 people in Sweden, 50,000-65,000 in Norway, 8,000 in Finland, and the remainder in Russia. ${ }^{18}$ They have their own languages, traditions, and resource-based livelihoods, such as reindeer herding. The Invit population makes up around $88 \%$ (about 50,000) of the total Greenlandic population and primarily speaks Greenlandic (Kalaallisut). ${ }^{19}$ In this section, indigenous business is defined as an enterprise or economic activity conducted by indigenous peoples for the purpose of developing, promoting, or commodifying traditional and modern indigenous culture.

Sami culture is closely linked to traditional Sami business practices, as these practices provide a foundation for cultural maintenance and development. In Finland, Norway, and Sweden, Sami culture is protected through similar Sami acts (with minor differences) and Sami parliaments that protect and develop their culture and language by giving Samis a platform through which they can influence national policy. Sami businesses often involve a diversity of activities operating locally and on a small scale. Especially important to both Sami tradition and business is the practice of reindeer herding. Reindeer herding occurs within a Samiby, which is a complex, economical administrative union created with the intention of keeping reindeer. Swedish Sami reindeer

SUMMARY: Indigenous businesses in the Nordic Arctic centre on the Sami population of northern Finland, Norway, and Sweden, and the Invit population of Greenland. Sami culture, language, and way of life are protected through the National Sami Acts and national Sami parliaments. One of the most prominent aspects of Sami culture is the tradition of reindeer herding.
This tradition has been protected by national legislation that designates areas for reindeer herding and generally limits the practise to the Sami people. Because the Inuit population in Greenland is by far the demographic majority, Greenlandic culture is Inuit culture. An important tradition is hunting marine mammals, including seals, which is supported through subsidies. 
In dáidda, Sami film is an important driver of business development. Sami people have produced many international recognized films, such as Sami Blood (2016), which was nominated for the Nordic Council Film Prize 2017. Dáidda business development is supported by various organisations and foundations, especially Sami Art Council. This council covers six Sami art organisations and plays an important role advocating for Sami dáidda and administrating different kinds of funding.

A central tradition of the Greenlandic people is sea mammal hunting. Such hunting is not only important in a cultural respect, but also in an economic respect, as sea mammal hunting still comprises a considerable part of the Greenlandic economy. In 2013, there were around 1,600 full-time hunters in Greenland, a number that has dropped from above 2000 full-time hunters in 2006. Seal catches reached close to 145,000 seals in 2013. In 2012, the total export value of sealskin was around EUR 1 million, an increase of EUR 0.5 million from the previous year. However, the export value of seal has fallen steadily from 2006, when it reached EUR 7.6 million. Despite these exports, meat and skin from seals, whales, and walruses are generally traded locally. However, subsidies are needed for most professional hunters to be able to continue hunting to supplement the local barter economy. ${ }^{23}$ Part of the reason for the decreased export values of seal skin have to do with the EU's ban on seal skin products. Although certified

"Sami indigenous businesses also entail music, art, and design activities, which have become increasingly important for the development of indigenous businesses and carry international potential whilst at the same time have an informative and educative purpose." sealskin from Greenland is exempted from the ban, it has led to a significant drop in global demand and prices, making it harder for Inuit hunters to make a living. Moreover, other Inuit traditions that yield both cultural and economic returns include the production of arts and crafts. These include works of bone, leather, and beads, which can be purchased by tourists.

The promotion of artistic indigenous businesses occurs through artistic funding from organisations such as the Nuna and Sermeq foundations in Greenland and NAPA (the Nordic Institute in Greenland), a cultural institute under the Nordic Council of Ministers. The Nuna foundation grants support based on humanitarian, social, health, cultural or sport related purposes. The Sermeq foundation is focusing on supporting public cultural activities for the citizens of Kommuneqarfik Sermersooq. Lastly, develops and supports Greenlandic cultural life through funds to individuals, organisations and institutions that are in need of financial support. ${ }^{24}$ The Greenlandic government also supports the development of Greenlandic culture through grants and funding. For example, in 2016, grants for cultural purposes amounted to DKK 63 million and support of the arts centre Katuaq amounted to DKK 5 million. ${ }^{25}$ 


\subsection{DRIVERS AND ENABLERS OF BUSINESS DEVELOPMENT}

In the Nordic Arctic, creative and cultural industries are growing rapidly in importance and are opening up for new business development opportunities. This section will outline the drivers and challenges present in the creative and cultural industries. However, as drivers and barriers of each of these industries differ substantially, the section will be segmented by industry rather than by drivers and enablers.

\section{Film}

The establishment of internationally recognized film industries has been widely successful across the Nordic Arctic, with the exception of Greenland and the Faroe Islands. A primary driver of this development is a financial rebate of reimbursement on production costs. In Iceland, Finland, and Norway, this reimbursement reaches $25 \%$ of production costs. It is generally based on the principle that a local production company is used in the filmmaking process. ${ }^{26}$ Iceland's experience with its rebate has shown that longer-term certainty and stability are important elements when developing an incentive system in the film industry. Hence, excessive rebates based on unstable political agreements are to be avoided, as this sends the wrong signals to the market. Even though the rebate is a key driver, it alone is not enough to develop a film industry, where external factors such as currency fluctuations also play a role in the international film market. Furthermore, when developing a rebate system, it is important to consider the economic sustainability of the rebate and the return it can offer compared to other policy incentives.

Capable production resources are a highly important compliment $\leftarrow \quad$ A drum dancer performing in Nuuk on National Day in Greenland. Photo: Mads Pihl / Visit Greenland to financial incentive structures. This includes service companies with considerable technical expertise and experience, as well as the ability to offer the whole menu of production services e.g. logistics, catering 
etc. The absence of professional filmmakers and producers, production expertise including sound designers and editors serve as a barrier in Greenland's and the Faroe Islands' film industries. Projects such as the North Atlantic Talents initiative that develops expertise and talent within the realm of film and general policy support, are attempting to address these issues. Norway and Sweden are also trying to increase the capabilities of service companies to attract more projects by collaborating closely with Icelandic service companies. International film and TV productions are challenging to handle, and service companies are often chosen based on experience. As such, Icelandic service companies have also become aware of other Arctic op-

"Capable production resources are a highly important compliment to financial incentive structures." portunities and are establishing foreign offices. For example, one of the largest service companies in Norway is Icelandic.

The development of indigenous film industries also show potential for increased growth. There is already an International Sami Film Institute in Norway, and Sami film makers tend to be well connected with Canadian and US film industries - a network in which Greenlandic filmmakers have also been included for the past few years. Notable initiatives related to indigenous films also include Skábmagovat, an Indigenous People's Film Festival in Inari, Finland. Here, other indigenous peoples besides Samis are invited to join and showcase their work. However, to drive the development of indigenous film in the Arctic even further, more resources are needed. The Nordic Co-operation has already voiced that indigenous film industries are in need of greater support. Film-related education especially requires more resources to ensure the development of competent local service providers and filmmakers. Currently, the International Sami Film institute and the Greenlandic film industry are working together - in a joint effort with Canada - to establish an Arctic Indigenous Film Fund that has the potential to significantly change the indigenous film landscape. Cross-border initiatives, like North Atlantic Talents, have the potential to increase knowledge sharing and best practices that can be utilised in other Nordic Arctic regions.

\section{Tourism}

Public support and public-private collaborations have proven important for the promotion and development of tourism activities. A notable initiative is Promote Iceland, which focuses on coordinated marketing efforts to attract tourists. ${ }^{27}$ After the volcano eruption of 2010, the tourist industry and the government joined forces to turn the negative attention of Iceland into positive stories to attract tourists. All the 
stakeholders were part of the preparation phase and together they developed the concept of "Inspired by Iceland". Through coordinated media campaigns, this concept managed to facilitate the reinvention of Iceland as a tourist destination. The strength of the project was the use of an integrated campaign in which the same story was communicated through different channels across different countries, social media, $T V$, and more. A major challenge for the project was to ensure that all companies and stakeholders knew what was going on. Promote Iceland addressed this issue through a strong focus on internal communication.

Increased communication among tourism actors may also help address the development of rural tourism, which often suffers from an uneven spatial distribution of available resources. It is often more difficult for rural regions to be promoted within national structures and government-funded institutions, as promotion of tourism by government bodies is often organised as top-down rather than bottom-up. This means that lesser-known, often rural locations receive much less promotional attention. ${ }^{28}$ Other forms of government support and public private collaborations include Norway's Arena Clusters. Within this overarching initiative, one programme promotes tourism in northern Norway through collaboration between tourism companies in Nordland, Troms, and Finnmark. The aim is to address the challenge of creating a sufficient year-round customer base by attracting tourists in the winter months, when tourist operators have the usual operation costs but inadequate customer numbers. Specific tools include improving the quality of experiences and making travel within the region easier in a region fraught with limited transportation infrastructure. ${ }^{29}$ Furthermore, it is important to know which customer segments are attracted to which areas and how these segments can be targeted.

Transnational collaboration is another key driver of the development of Arctic tourism. The Arctic regions, especially those in Finland, Norway, and Sweden, are generally perceived as one destination by the tourism market. Collaboration amongst Arctic regions may therefore help increase awareness of the Arctic as an interesting tourist destination in both the minds of tourists as well as Nordic Arctic governments. In 2015, this spurred the collaboration between Visit Northern Norway, Swedish Lapland Visitors Board, and Finnish Lapland Tourist Board to create Visit Arctic Europe. Other collaborations include the North Atlantic Tourist Association between the Faroe Islands, Greenland, and Iceland for joint promotion and marketing of tourism in the West Nordic region. ${ }^{30}$ Presenting the Arctic region as one destination may also help address the lack of accessibility to tourism in the Nordic Arctic region, as it could lead to an improvement in Arctic transportation infrastructure such as flight, train, and bus connections between Arctic regions. ${ }^{31}$

Finally, a growing demand for activities centred on the dramatic natural environments that characterise Nordic Arctic regions has been 


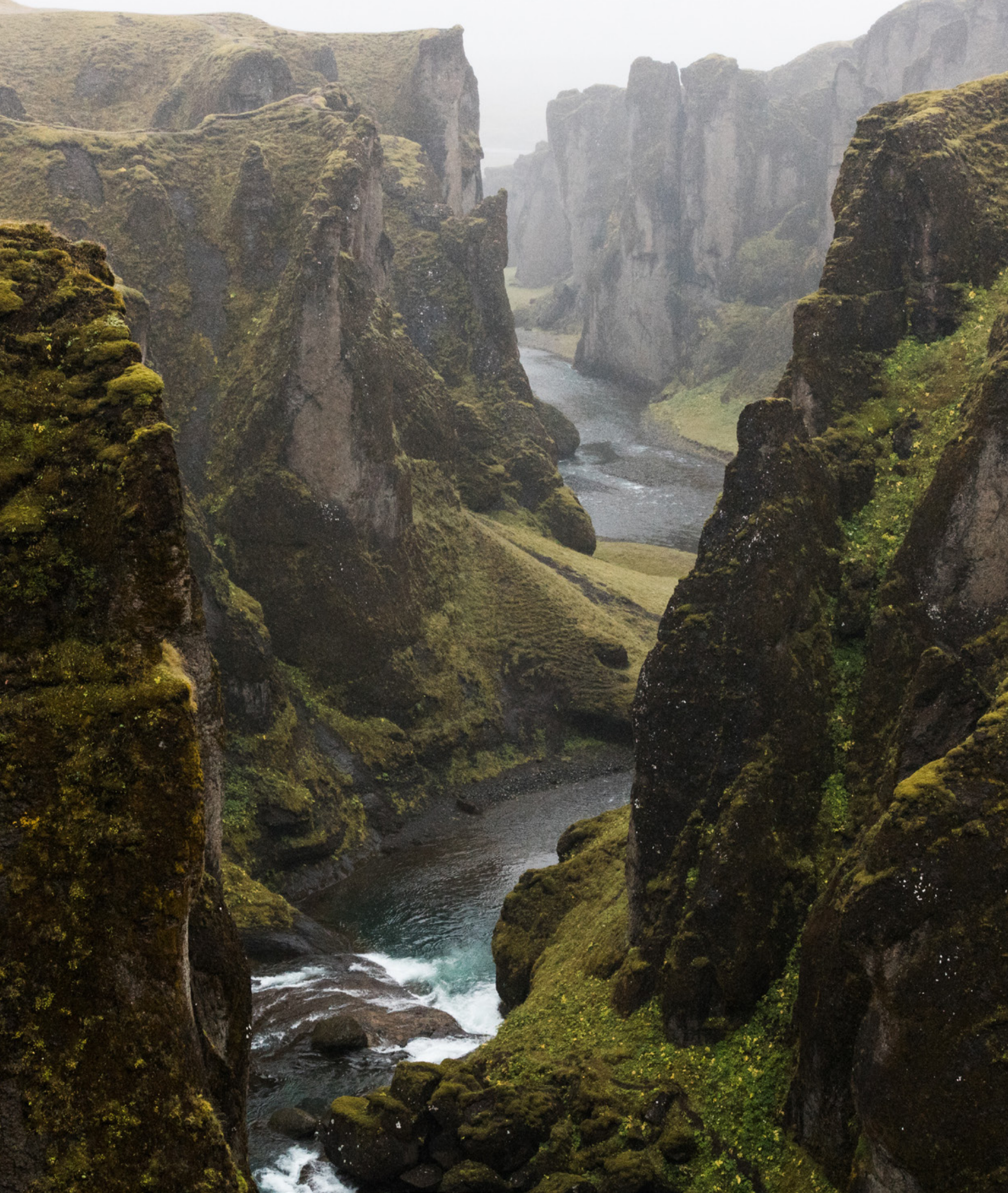


a driver for tourism growth. ${ }^{32}$ To take advantage of these opportunities, a key enabler is to commodify wild nature and make it accessible for tourists. This would have to be done in a highly sustainable way that conserves nature. This could be achieved through infrastructure projects or collaboration between local partners on, for instance, product and experience development and innovation.

\section{Indigenous business}

An important driver for indigenous business development in the Nordic Arctic regions is cross-border collaboration and connectivity. Cross-border connectivity and collaboration for the Sami population is of great importance, as it can create synergies and a critical mass necessary for innovation and a competitive advantage within the global economy. As Sápmi, Sami people's land, covers Norwegian, Swedish, Finnish, and Russian territories, cross-border collaboration will make it easier for the Sami people to live as one people and engage in cross-border commercial activities within Sápmi. Collaboration between the Sami parliaments could also be strengthened to promote Sami issues at an international level, e.g. having a representative from each Sami parliament in Brussels to help promote the Sami voice at

"Cross-border connectivity and collaboration in the Arctic in general and for the Sami population is of great importance in order to create synergies and a critical mass necessary for innovation and a competitive advantage within the global economy." an EU level. Steps towards greater collaboration have already been taken with the Nordic Sami Convention, signed on 13 January 2017. The convention concerns a unified Nordic approach to Sami rights and culture and establishes voter eligibility in Sami parliament elections. However, the convention still needs to be ratified in the national parliaments.

Sami business development is also challenged in terms of public project funding, as its territories are covered by different jurisdictions. Sweden and Finland are members of the EU, while Norway and Russia are not. However, Norway does have close relations to the EU and participates in some EU programmes. Implementing projects to promote economic growth and business development across Sápmi thereby requires transnational funding opportunities aimed at Sami projects. EU programmes have been important sources of funding opportunities for pan-Sápmi projects focusing on culture, education, and entrepreneurship. ${ }^{33}$ Still, it is vital that funding opportunities consider the special circumstances that certain Sami projects are subject to. This ranges from acknowledging the cultural value that Sami businesses can create and that many Sami projects do not necessarily offer benefits on the same scale with regards to job creation, profit, 
etc., as other non-indigenous projects. This does not necessarily make these projects less important. However, a general awareness of ways to measure and assess the total economic, social, and cultural value of indigenous projects has the potential to improve business development in indigenous communities.

Another major driver for indigenous business development is the development of tourism. Tourism offers opportunities to leverage indigenous culture and natural surroundings. Potential for business development exists on a company level, as well as on community or village levels (community-based business), which could increase cultural niche and eco-tourism. Greater funding is needed to develop such initiatives, such as funding education and training in tourism, marketing and branding activities, and product development that not only reflects tourism but also other indigenous businesses. Activities could relate to digital marketing of indigenous products and fostering the use of ICT technology and social media. There is also significant potential in combining tourism with traditional businesses such as reindeer herding, which can provide additional income without disturbing the reindeer or nature if done sustainably. Moreover, tourism can be combined with hunting or fishing (depending on the time of the year), which allows tourists to access the considerable knowledge of the Sami and Invit people on nature.

Finally, a major challenge for indigenous traditions is the misrepresentation and appropriation of indigenous life and creative work. Sami people often experience their culture misrepresented in marketing campaigns. For example, tourism companies often use pictures of what can be called "fake" Sami people and offer cultural activities said to be related to Sami traditions but are not. Indigenous people perceive this as unethical and as potentially harming their culture. One could argue that such practices violate the "cultural copyrights" of Sami people. This is an area of common concern for indigenous peoples throughout the Arctic and the world, and is an area for which collaboration across indigenous nations should be encouraged to perhaps extend certification of an Arctic-wide programme.

Already, two separate initiatives have attempted to develop guidelines on ethnical representation of Sami culture in tourism activities. Visit Sápmi in Sweden developed a quality assurance system for Sami touristm businesses (see case study), while House of Lapland has developed a guide to accurately present Sami culture in branding. Furthermore, a new global initiative has been launched to develop the first guide to support visual designers developing culturally-aware 
$\downarrow \quad$ Nuuk art museum. Photo: Visit Greenland renderings and interpretations of indigenous design in their work. The initiative is called the Indigenous Design Charter and was launched by Deakin University in Australia. The charter presents ten points that cover different stages of the design process and which emphasise the need for open and respectful dialogue with the intention to learn from both indigenous and non-indigenous designers. It is currently expanding globally in collaboration with stakeholders in the Arctic. The plan is to include the indigenous design of Inuit and Sami people. However, initiatives like this are not being welcomed by all indigenous people, as some view it as an opportunity for exploiting and marketing indigenous culture instead of an opportunity for respectful business development.

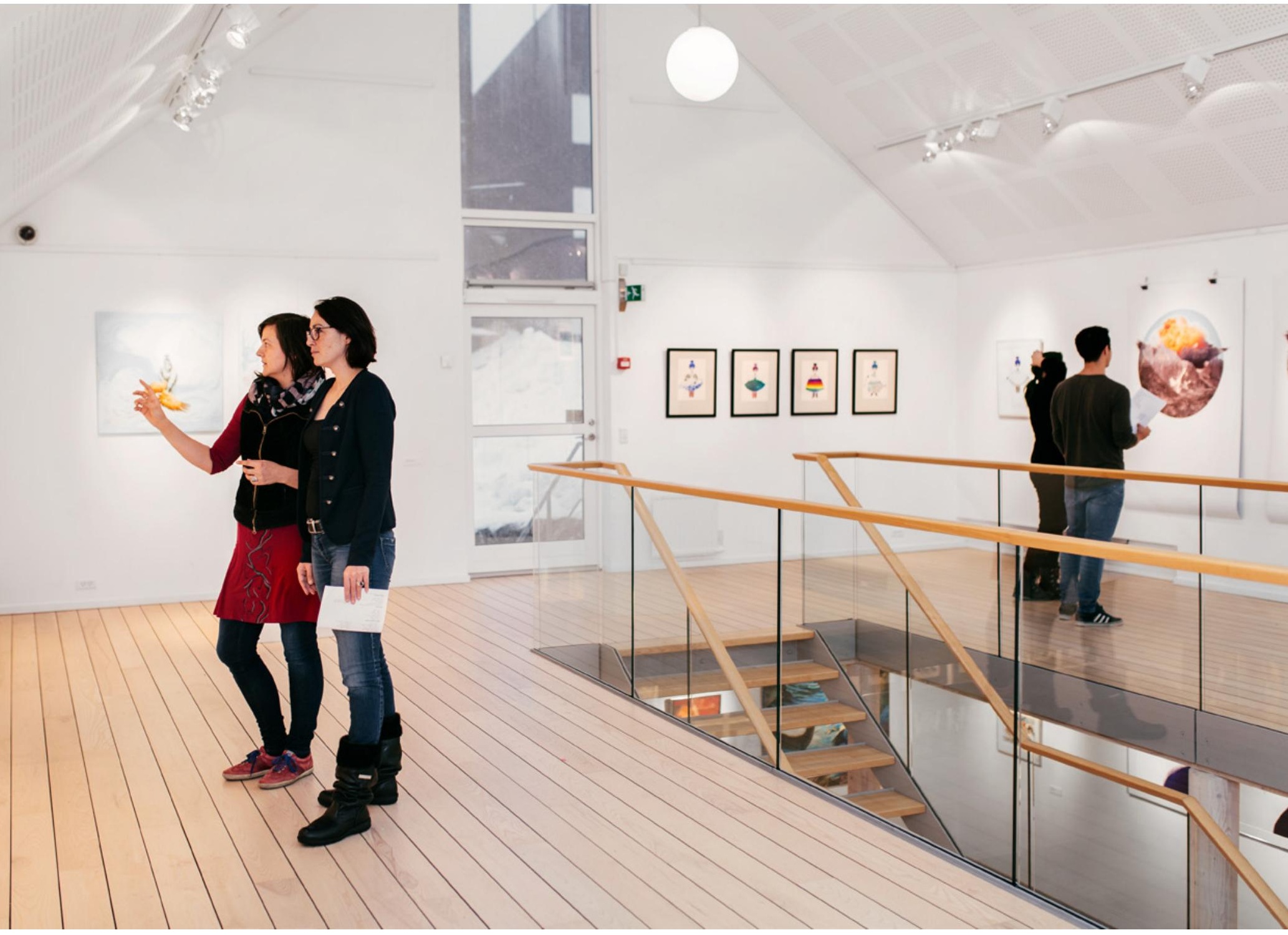




\section{OPPORTUNITES FOR SMALL SCALE TOURISM: A GREENLANDIC GUEST FARM}

\author{
Organisation: Ipiutaq guest farm \\ Sector: Tourism \\ Region: Greenland
}

\author{
Contact: Agathe Devisme \\ Co-founder \\ Mail: info@ipiutaq.gl
}

\section{Combining traditional farming and tourism to explore opportunities for local and personal tourist experiences in the Arctic.}

The Ipiutaq guest farm is the story of a meeting between French and Greenlandic culture and the dream to develop a guest farm where Greenland can be experienced through nature, food, and close relations with the inhabitants. The owners and founders, Agathe Devisme and Kalista Poulsen, started the Ipiutaq guest farm in 2007. It was the first guest farm in Greenland founded on a dual economy: agriculture (sheep farming) and tourism. Since then, the guest farm has expanded and can now welcome 6-8 people in a guest house. The expansion has been followed by high growth, and in the last five years, the number of overnight stays has increased by $130 \%$ to 129 overnight stays by 42 different people in 2016 (only open during the summer). Ipiutaq guest farm offers gourmet food based on local products by Agathe, hikes in the surroundings of the farm and tours in the area, as well as arctic char fishing in the clear water river and lake system llua, to which Ipiutaq guest farm has the exclusive rights to use for sport fish- ing tourism. The rights were granted through a fishing concession from the Government of Greenland in 2013.

\section{Success factors}

At the Ipiutag guest farm, tourists can experience the harsh wild nature with the comforts of home. Key to their success is a strong focus on marketing, close collaboration with Greenlandic stakeholders, high quality rather than large scale, and personal customer relations. Agathe and Kalista focused on building a concept where they were in direct contact with the customers to allow them to feel secure and welcome, already from the booking process. They have attracted customers by promoting the guest farm through its own website, advertising on Visit Greenland's website, and participating in interviews for news articles, radio programs, and films. To make the experience unique and sustainable, they have a strong 


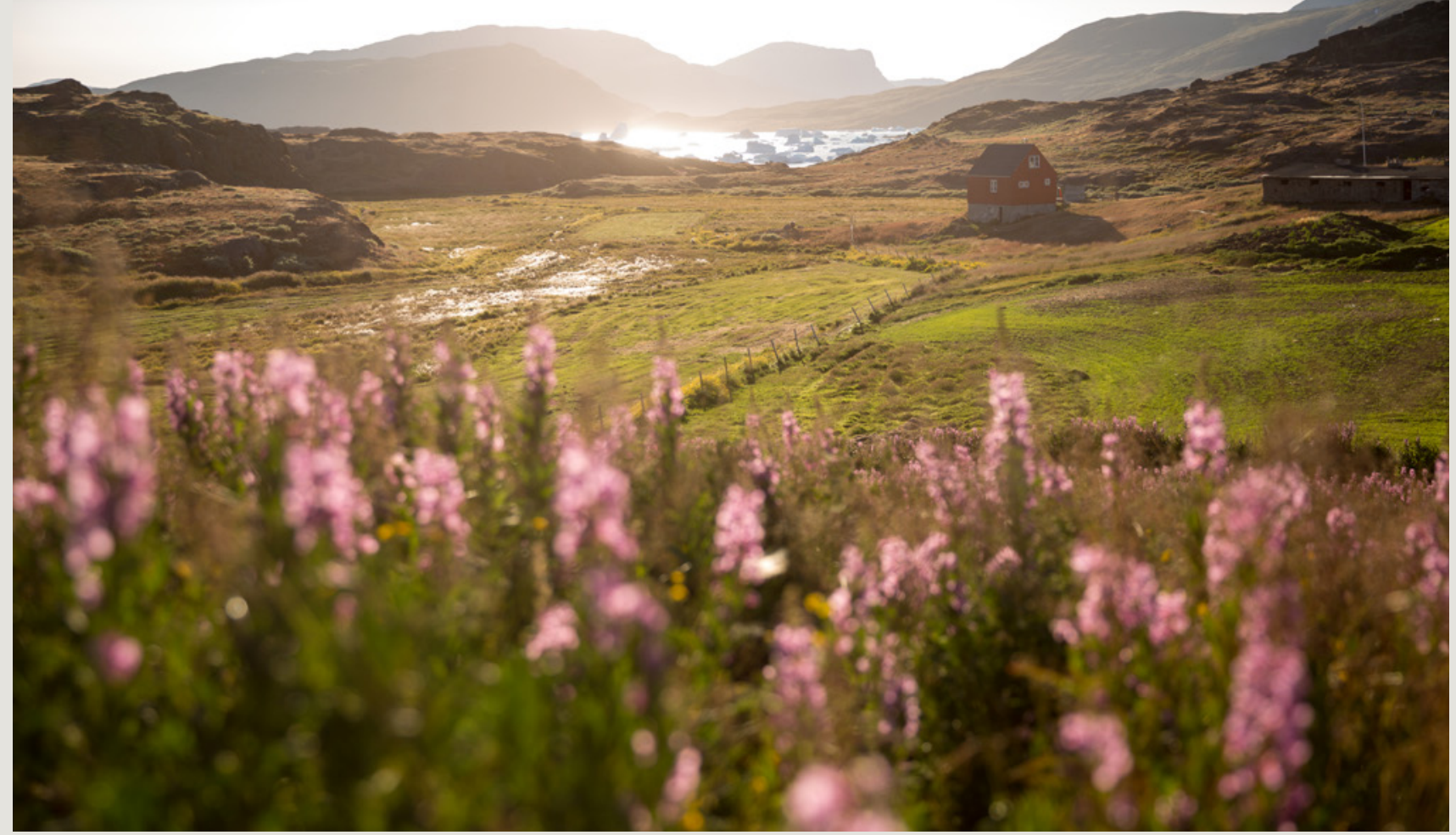

$\uparrow \quad$ Tasiusaq in South Greenland. Photo: Mads Pihl / Visit Greenland

focus on high quality food, energy production from solar panels and a windmill, as well as a focus on sorting their garbage. They also work closely with local partners such as Blue Ice Explorer to transport their guests to the farm, Visit Greenland to promote the guest farm, and the government, which has provided advice and financial support for the company.

\section{Drivers and challenges}

Tourism in Greenland is strongly driven by the beauty of its nature, people, and taking opportunities to make nature accessible in a sustainable way. Furthermore, support from the different government institutions in terms of grants, loans, advice, and general support is vital to develop a sustainable business.

Yet, the tourism industry is challenged by several barriers such as expensive and limited transportation possibilities, harsh and unstable weather conditions that make some areas inaccessible during the winter, and a lack of local, dynamic, and long-term tourism collaborations, for example through local tourism offices. In addition to this, a major challenge is the lack of an entrepreneurial culture that celebrates and promotes an entrepreneurial spirit that focuses on agility, simplicity, and collaboration when developing projects or businesses.

\section{IPIUTAQ GUEST}

\section{FARM'S AWARDS}

$\rightarrow$ Entrepreneur of the Year, 2011 (Bank of Greenland)

$\rightarrow$ Greenland's Nature and Environment Award, 2012 (Government of Greenland)

$\rightarrow$ Award of the Year, 2013 (Brugseni) (shared with Hotel Arctic in Ilulissat) 


\section{THE DEVELOPMENT OF A PROSPEROUS FILM INDUSTRY IN ICELAND}

\author{
Organisation: Film in Iceland \\ Sector: Film industry \\ Region: Iceland
}

\author{
Contact: Einar Hansen Tomasson \\ Film Commissioner \\ Mail: einar@filminiceland.com
}

\section{The role of external factors in developing a sustainable film industry in Iceland and the importance of a sustainable and stable production cost rebate.}

Iceland is home to the one of the most developed film industries in the Nordic Arctic. Numerous high-profile Hollywood blockbuster projects have already visited the island, e.g. Game of Thrones, Star Wars, Prometheus and more visiting each year. In 2014 the industry reached a production value of over EUR 107.7 million, and from 2010 to 2014, the turnover of the industry increased by $300 \%$. Key to this development has been the introduction of a temporary rebate for production costs incurred in Iceland. The rebate was originally introduced in 1999 at $12 \%$ but has increased to $14 \%$ and then $20 \%$. In 2017 it was set at 25\% and extended to 2021. As part of promoting film production in Iceland, the organisation "Film in Iceland" was established and has since 2001 promoted Iceland to Hollywood studios and location managers to attract film productions to the country.

\section{Success factors}

Key to the extreme success after 2010 are three unrelated factors. First was the eruption of the volcano Eyjafjallajökull that became a huge marketing opportunity for Iceland, which had never experienced such levels of media coverage. Second, the film rebate was increased from $14 \%$ to $20 \%$. Third, the Icelandic currency was devalued dramatically after the financial crisis of 2008. Hence, the combination of media publicity, a high incentive, and a weak currency enabled the Icelandic film industry to grow enormously.

\section{Drivers and challenges}

The main driver of the development of the film industry is the rebate incentive. Without this, location and production managers would not 


\section{PROMOTING SAMI TOURISM: LESSONS LEARNED FROM VISIT SÁPMI}

\author{
Organisation: Visit Sápmi \\ Sector: Tourism \\ Region: Swedish part of Sápmi
}

\author{
Contact: Jerker Bexelius \\ Head of organisation, Gaaltije \\ Sydsamisk Kulturcentrum \\ Mail: jerker@gaaltje.se
}

\section{The promotion of Sami tourism through a certification system, and the challenges related to financing a Sami tourist activities.}

In Sápmi the indigenous Sami culture is considered an asset for developing a tourism industry. Sami tourism includes museums, cultural events, and outdoor activities, among many other things. Tourism is a natural complement to the traditional professions because of Sami people's access to and knowledge of nature, as well as their rich culture. Furthermore, tourism is also a way to diversify the Sami economy and generate new sources of income. To promote and support Sami tourism, the Swedish Sami Association (an NGO representing members of Sami co-operatives and Sami associations) established the project Visit Sápmi in 2008. The aim was to influence the development of Sami tourism and to help Sami people profit from it. Visit Sápmi was funded through local and EU funding.

\section{Success factors}

A great success of Visit Sápmi was the development of Sápmi Experience, a brand name and quality assurance system for the true Sami tourism experience, developed in collaboration with Visit Sweden. Sami tourism was challenged by non-Sami tourist operations who misrepresented Sami culture in marketing and tourist activities. The quality assurance system was a certification for Sami tourism if the company fulfilled certain criteria and followed a set of ethical guidelines. To complement the system, Visit Sápmi held courses to introduce companies to the certification and advised companies on developing their business, with a focus on marketing.

In addition to Sápmi Experince, Visit Sápmi also wanted to develop a sponsorship and certification system called Friends of Sápmi to enable non-Sami companies to show their 


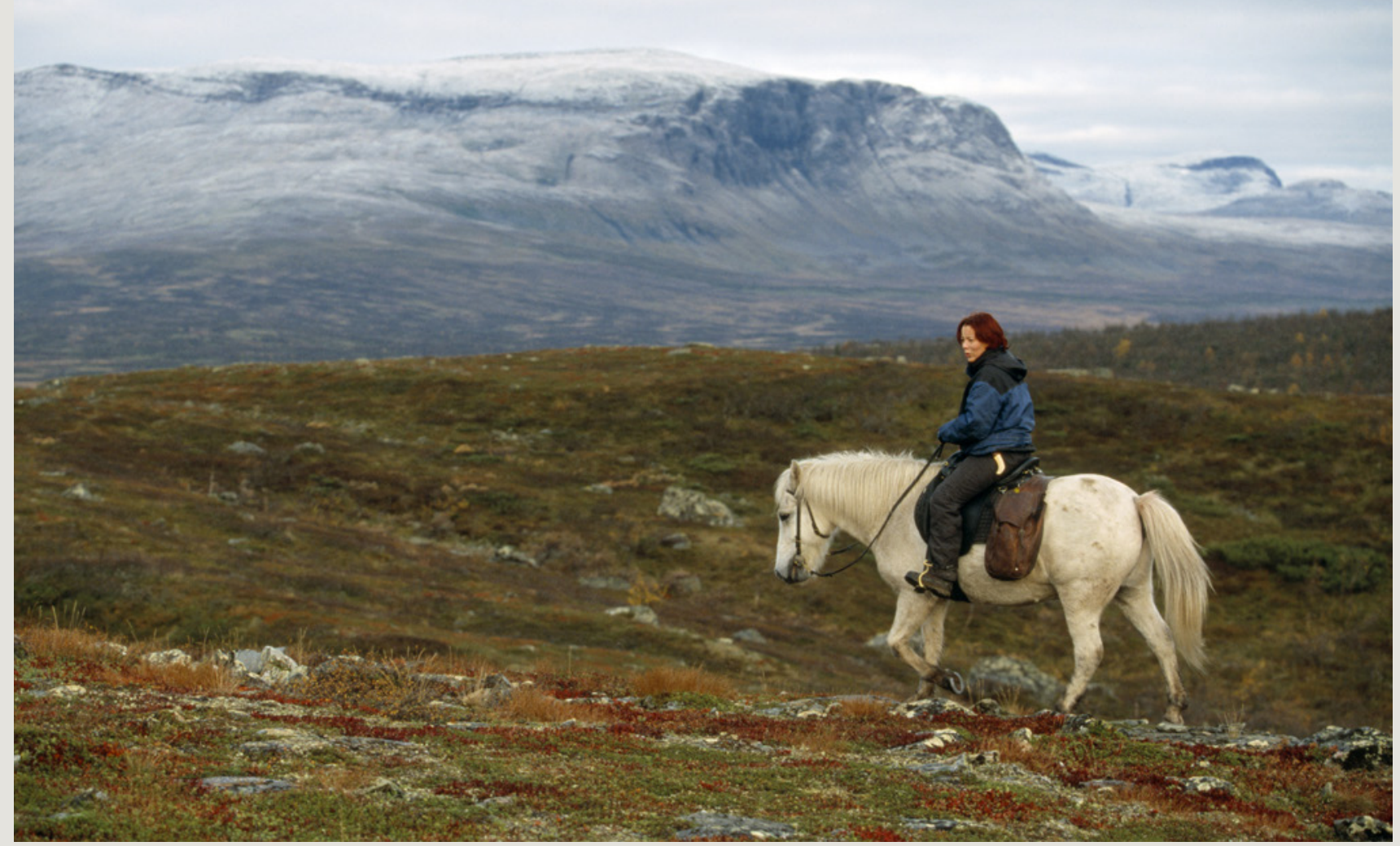

$\uparrow \quad$ Sami woman rider on a horse, Sweden. Photo: Scanpix

support for the protection of Sami culture. The certification was however never implemented, as Visit Sámpi struggled to find funds to continue its work. Currently, Visit Sápmi technically exists but is not active and the plan is to close the organisation in the near future.

A key lesson to be learned from Visit Sápmi is the need to incorporate a much bigger picture instead of relying solely on local perspectives. Success requires collaboration towards a common goal. The process involves openness and the ability to listen and communicate with many different types of stakeholders to understand the different needs, but also to influence stakeholders' views.

\section{Drivers and challenges}

A major challenge for Sami tourism projects is the lack of funding. Sami projects gener- ally have the same funding opportunities as non-Sami projects. But, compared to these projects, Sami projects are often much smaller in scale and they find it difficult to fulfil the required impact criteria from different funding programmes, e.g. a specific number of jobs created. Furthermore, many Sami people feel that the committees of the funding organisations do not understand the Sami culture and its specific needs when assessing their funding applications. In addition, lack of cross-border financing limits the ability of Sami tourism projects to cover all of Sápmi, and projects are therefore often forced to keep a more local focus, for example the Swedish part of Sápmi.

Finally, a key concern for Sami people is how tourism influences the Sami culture and potentially disturbs the reindeer. Sami people are divided on these issues and tourism development is a balancing act between risk and opportunity. 

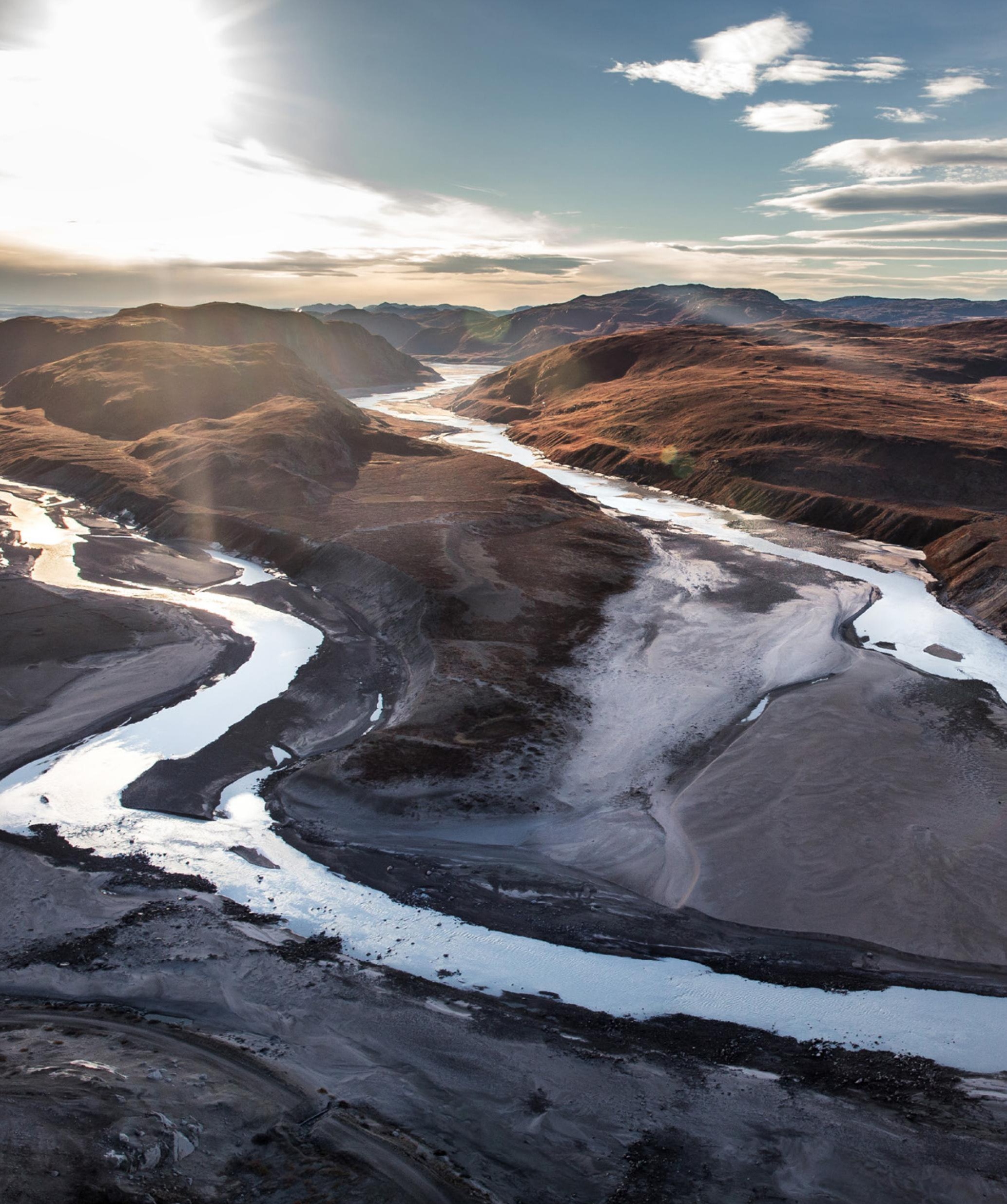
EXAMPLE: In 2015, the demand for co-operation spurred the collaboration between Visit Northern Norway, the Swedish Lapland Visitors Board and the Finnish Lapland Tourist Board to create Visit Arctic Europe. Another notable collaboration includes the North Atlantic Tourism Association (NATA), a collaboration between Greenland, Iceland, and the Faroe Islands to promote tourism in the West Nordic countries. $\leftarrow$ Kangerlussuaq

in Greenland.

Photo: Mads Pihl / Visit Greenland
The recommendations presented below revolve around opportunities to promote sustainable economic development within the Nordic Co-operation, specifically the Nordic Council of Ministers (NCM), as well as other Nordic Arctic stakeholders.

\section{Developing an Arctic image}

RECOMMENDATION: Strengthen cross-border collaboration and marketing promotions with the aim of supporting the development of a sustainable Nordic Arctic tourism brand.

$\rightarrow \quad$ Why: The Nordic Arctic region is generally perceived as one destination by the global tourism market, as regions within have similar climates, offer similar nature experiences, and represent unique Nordic cultures.

$\rightarrow \quad$ What: To ensure the potential demand for Nordic Arctic tourism is met, collaboration amongst Nordic Arctic regions may help increase the awareness of the Arctic as an interesting tourist destination in both the minds of tourists as well as Nordic Arctic governments. Presenting a unified Nordic Arctic region may also help address the lack of accessibility for tourism in certain areas, as it could increase future flight, train, and bus connections within Nordic Arctic regions.

$\rightarrow \quad$ Who: The continuation and/or support of programmes like Visit Arctic Europe and NATA is important for developing tourism in the Nordic Arctic. The organisations can also play a role in gathering Nordic Arctic-specific tourism data to ensure nuanced and fact-based debates on Nordic Arctic tourism (see overall recommendation). Strengthening the Arctic dimension can also be achieved through AEC's considerable network, through which new collaborations and Arctic tourism marketing campaigns 
could be expanded. Furthermore, in 2016 the Nordic Council of Ministers for Energy, Industry and Regional Development (MRNER) placed tourism co-operation on the agenda for the coming years and existing efforts could possibly be seen in this context.

Next steps: The Visit Arctic Europe project should help drive change and further development of the project and/or similar projects. Similar evaluation could be made for NATA. Furthermore, as part of the potential evaluation, it should be investigated if the organisations can play a role in the collection and dissemination of Arctic-specific tourism data to promote awareness of the role of tourism in the Arctic regions - similar to the existing efforts of House of Lapland. ${ }^{34}$

\section{Promotion of competence exchange in the film industry}

RECOMMENDATION: Promote cross-border collaboration in development of competencies and expertise related to filmmaking and production through knowledge sharing forums, and technical and creative training programmes.

$\rightarrow \quad$ Why: An important driver of film development complementary to existing financial support mechanisms is capable creative and technical film production resources. This not only includes film makers themselves, but also production companies with considerable technical and local expertise and experience. This is especially absent in the Faroe Islands and Greenland, whose nascent film industries are hampered by an absence of professional film-makers and producers, and related expertise such as audio-visual designers and editors.

$\rightarrow \quad$ What: Facilitate collaboration between Nordic Arctic filmmakers, production companies etc. through knowledge and best practice sharing, as well as specific technical and creative training programmes to improve the capacity of local film industries in the Arctic.

$\rightarrow \quad$ Who: Projects related to cross-border collaboration and knowledge sharing concerning filmmaking could be part of the Nordic Culture Fund and their work on gathering knowledge and information, building networks, and providing financial support in the Nordic regions. Projects could also be part of the Nordic Culture Point and their work on enhancing the sense of Nordic cultural affinity, as well as the Nordic Film and TV fund and their financial support of feature films, TV-fiction / series, and creative documentaries.
EXAMPLE: Projects such as the North Atlantic Talents initiative, focusing on developing expertise and talent within the realm of film and general policy support, are attempting to address capacity building issues. An initial finding related to the project stressed the need for the creation of formal training programmes and film education in Iceland, Greenland, and the Faroe Islands. The lack of formal training often leads to a situation in which local resources are not adequate to carry out the required tasks. Norway and Sweden are also trying to develop the capabilities of their service companies to attract more projects by collaborating closely with Icelandic service companies. International film and TV productions are challenging to handle, and service companies are often chosen based on experience. As such, Icelandic service companies have become aware of other Arctic opportunities and are establishing foreign offices.

\footnotetext{
$\rightarrow \quad$ The deckhand line fishing on a tour with Arctic Boat Charter in the Nuuk fjord in Greenland. Photo: Visit Greenland
} 
Next steps: A first step would be to strengthen cross-border networks between national film-funds, filmmakers, technical production companies etc. to make cross-border contact, knowledge sharing, and project collaboration easier. Second, using the extensive networks of the Nordic Culture Fund, the Nordic Culture Point and the Nordic Film and TV fund, these bodies could facilitate the creation of official training programmes and knowledge sharing forums across the Nordic Arctic, and support them financially to ensure their sustained presence and benefit.

\section{Promotion and representation of indigenous culture and creative industries}

RECOMMENDATION: Facilitate and support the promotion and representation of indigenous creative industries, culture, life, and creative work.

$\rightarrow \quad$ Why: A major challenge for indigenous businesses is exploitation, misrepresentation and appropriation of their culture, creative work, handicrafts, and symbols by companies or individuals who are unaware of any cultural sensitivities and ways to incorporate indigenous culture in a business context. Examples of such challenges include the marketing of fake Sami pictures and offering cultural activities marketed as Sami-related when they are not. What: To combat these practices, a few initiatives have been implemented. At a regional level, Visit Sápmi developed a quality assurance system for branding real Sami tourism experiences. However, this is not actively used anymore due to funding issues. The House of Lapland has devised a number of guidelines on accurately promoting Sami culture in tourism marketing. At a global level, an initiative has been launched to develop the first guide to support visual designers in developing culturally aware and precise renderings of indigenous design in their work. The initiative is called the Indigenous Design Charter and was launched by Deakin University in Australia.

$\rightarrow \quad$ Who: To support the promotion and representation of indigenous culture, life, creative work, and handicrafts, the Nordic Council of Ministers' Arctic Co-operation Programme and the Nordic Council of Ministers for Culture (MR-K) potentially have an important role to play. As part of their Strategy for Cultural Co-operation 2013-2020, the MR-K can aim to ensure that the overall cultural and linguistic heritage of Sami and Inuit populations enjoy cultural continuity and continuity in representation abroad by supporting or promoting initiatives like the examples mentioned above. 


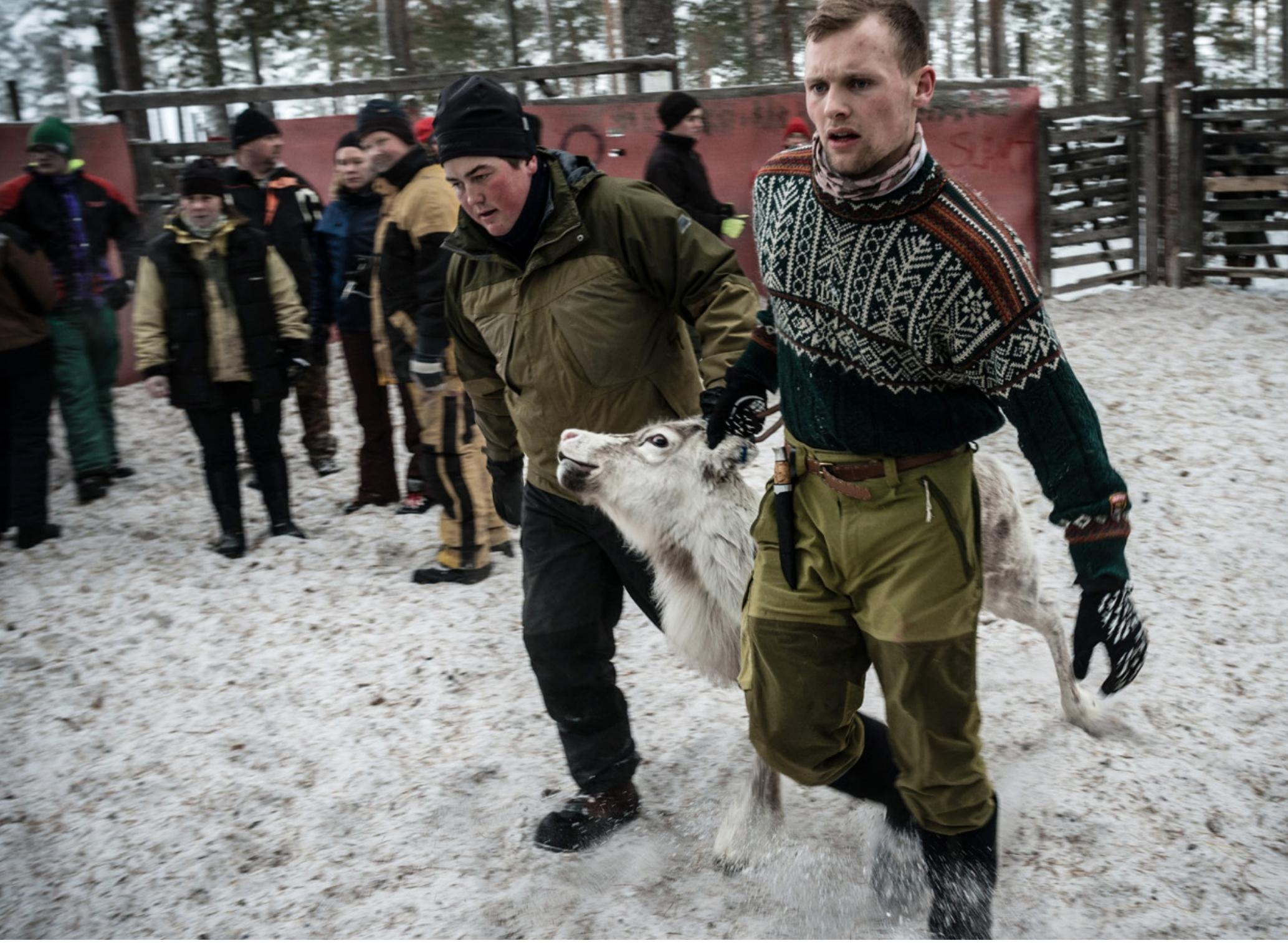

$\uparrow \quad$ Reindeer herding with Sami in Sweden. Photo: Scanpix

MR-K may also facilitate a synthetisation of relevant and current knowledge, analysis, and facts to enable a more responsible portrayal and development of Nordic Arctic indigenous culture and heritage, especially in areas like tourism.

$\rightarrow \quad$ Next steps: The work on the Indigenous Design Charter currently in development is envisioned to become a global charter that can act as a foundation for locally-adapted versions. In the Arctic region, MR-K could potentially take lead, follow, and participate in the process by facilitating and collecting input from Arctic stakeholders through workshops and events. To kick-off this process, an initial meeting with Deakin University is recommended. 


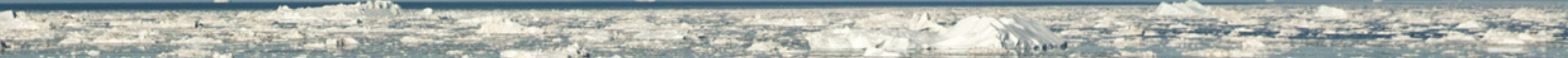

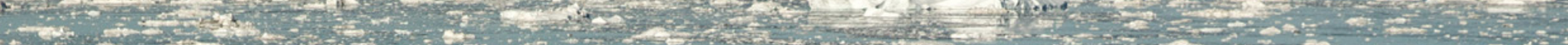

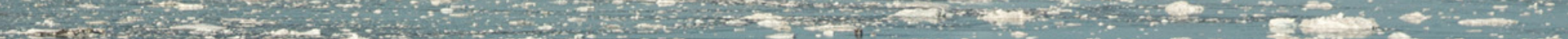

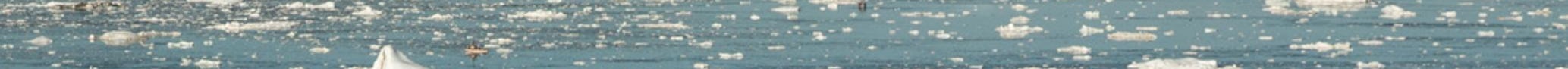

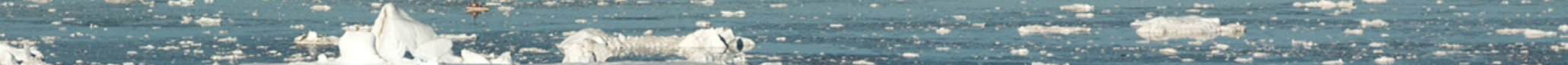
W.

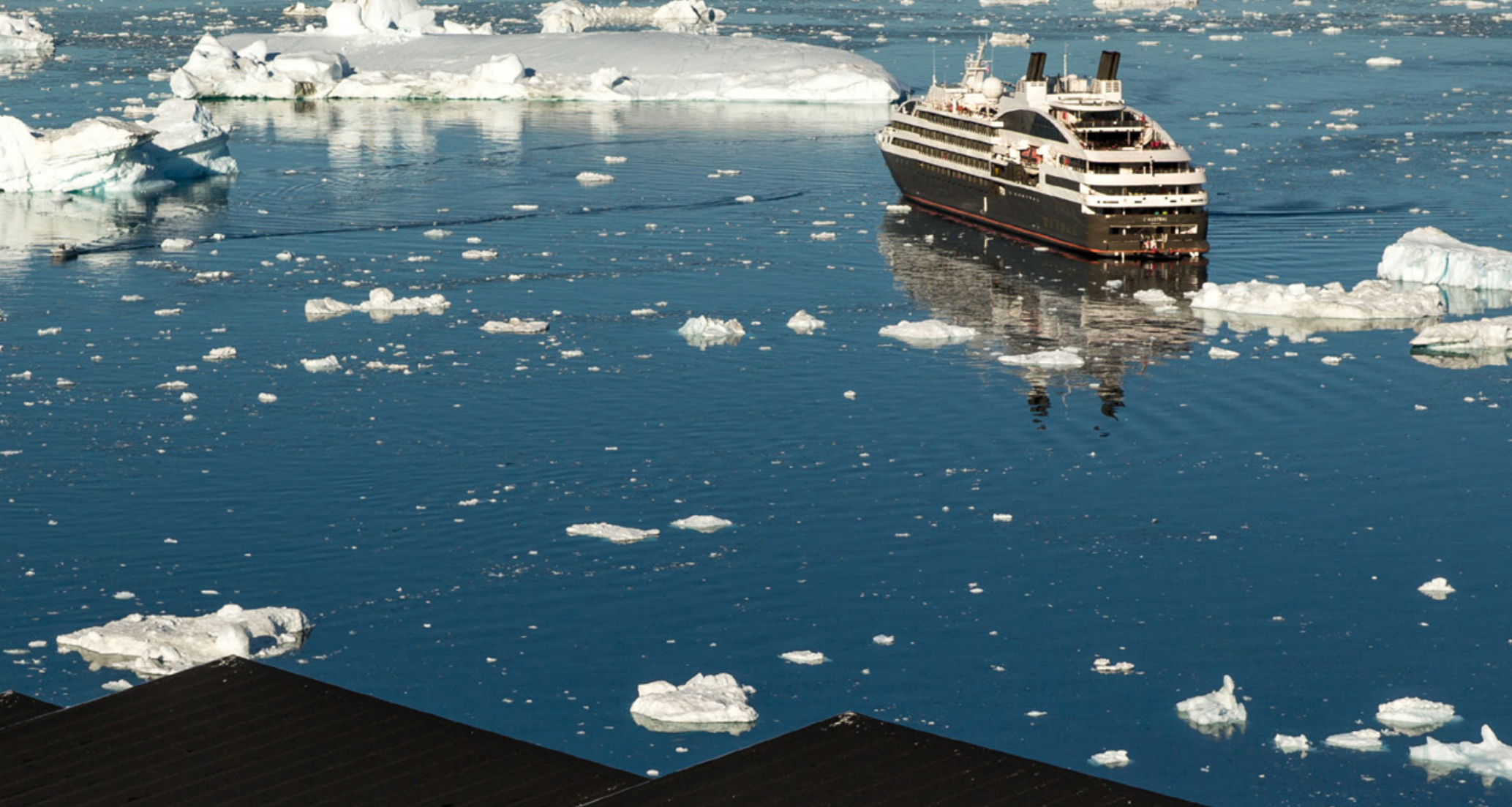

1)

D.

DIII

4

set

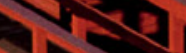

8

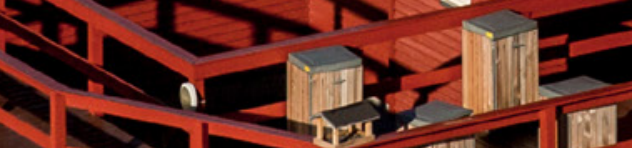
$1 \frac{1}{2}$

-

- I'D

[1. I.

(1) 


\section{CROSS-CUTTING ISSUE ACROSS THE ARCTIC BUSINESS ANALYSIS}

Desk research, case studies, and interviews have uncovered a variety of recommendations and practical tools to promote sustainable economic development for each focal area in the Arctic. These are presented in the individual reports, this one focusing on creative and cultural industries. However, the study also reveals a cross-cutting issue related to Arctic-specific data related to business development. Hence, presented below is a cross-cutting recommendation on data collection and dissemination

$\leftarrow$ Cruise ship near Illussat, Greenland. Photo: Mads Pihl / Visit Greenland

\section{A need for Arctic-specific data}

RECOMMENDATION: Promote and support a regular collection and dissemination of Arctic specific data related to business and societal development within the Nordic region by supporting national and Nordic statistical offices in data collection and dissemination or Arctic specific data gathering projects.

$\rightarrow \quad$ Why: The Nordic Arctic region offers great potential for business development but has limited Nordic Arctic-specific data to uncover the conditions in which companies operate, social and business opportunities and challenges, resources, future investment 
opportunities, as well as other aspects of the Arctic business environment. The limited data makes it challenging for stakeholders such as businesses, academics, governments, authorities, and media to engage in more nuanced and accurate discussion on the Arctic-specific needs in business development.

$\rightarrow \quad$ What: There is a need to supplement existing statistical information with systematic and recurring information gathering to develop knowledge of the Arctic specific socio-economic developments and business opportunities.

$\rightarrow \quad$ Who: To strengthen and promote the collection and dissemination of Arctic specific data, the Nordic Co-operation could consider supporting the expansion and long-term sustainability of projects like Business Index North, and ensuring knowledge and awareness of the data by including it in the Nordic Statistical Bank.

$\rightarrow \quad$ Next steps: To promote Arctic-specific data, the national statistical offices or the Nordic Statistical Bank could reach out to the Arctic data collection projects e.g. Business Index North to discuss possible collaborations on how to collect and disseminate data on the Arctic. Furthermore, a dialogue with Arctic business clusters, like the AEC, could be initiated to map the specific information needed.

EXAMPLE: Arctic-specific data gathering e.g. include the Arctic Business Forum Yearbook developed by Lapland Chamber of Commerce, the Economy of the North (ECONOR) publication by statistics Norway, and the Business Index North project implemented mainly by High North Center at Nord University Business School in Norway in Bodø. The Yearbook presents an overview of certain European High North investments and business developments, and discusses actions to be taken to overcome barriers of business and trade. It also presents data on specific investment opportunities and projects. The Business Index North initiative is a project that runs from November 2015 to December 2018, and is developed through a strategic partnership between academic and research organisations, authorities, and commercial partners from Norway, Russia, Finland, and Sweden. It presents knowledge and statistics on the northern areas of Norway, Sweden and Finland but will gradually expand its analysis to cover the northern regions of Russia, USA, Canada, Denmark (Greenland), and Iceland. ECONOR presents an overview of the circumpolar Arctic economy, including traditional production activities of indigenous peoples, and has been published three times since 2006. 


\section{METHODOLOGY}

\section{Objectives \& Definitions}

The overall goal of this study is to provide a better understanding of the Nordic Arctic business environment with a focus on sustainable economic activities; and to generate practical recommendations to the Nordic co-operation and other Arctic actors on increasing economic activity in the Nordic Arctic. To this end, the research scope includes four focal areas selected by the steering group as areas of particular interest for sustainable business development in the Nordic Arctic. The Nordic Arctic and the four focal areas are defined below.

The Nordic Arctic is defined as the states of Iceland, Norway, Finland, Sweden and the countries Faroe Islands and Greenland (part of The Kingdom of Denmark). ${ }^{35}$ The study will include an overall analysis of the areas mentioned, but for Sweden, Norway, and Finland emphasis will be placed on the northern regions of these countries.

\section{Entrepreneurship and innovation}

$\rightarrow \quad$ Entrepreneurship is when actions take place on the basis of opportunities and good ideas, and are translated into economic, social and/or cultural value for others. ${ }^{36}$ Along similar lines, innovation is the process of promoting changes in technologies, products, or administrative practices. It is important, however, that the understanding of entrepreneurship, innovation, and an entrepreneurial mind-set is embedded within regional and cultural contexts.

Public-private partnerships (PPPs) and business co-operation

$\rightarrow \quad$ PPPs are an interaction between public and private institutions for the delivery of pre-defined services. The aim is to provide public service delivery from a mutually beneficial partnership, though the partnership remains founded in public oversight. ${ }^{37}$ 
$\rightarrow \quad$ Business co-operation is, in this report, defined as industry clusters, where the seminal definition is a "...geographical concentration of interconnected companies, specialised suppliers, and associated institutions (e.g., universities, standards agencies, trade associations) in a particular field that compete but also co-operate." This definition is combined with the European Cluster Excellence programmes labelling to specify the clusters. ${ }^{38}$

\section{Bioeconomy}

$\rightarrow \quad$ Bioeconomy consists of the management of renewable biological resources and their conversion into food, livestock feed, bio-based products, and bioenergy via innovative and efficient technologies. It means using biomass intelligently and creatively through the four pillars of bioeconomy: collaborate, circulate, upgrade, and replace. $^{39}$

\section{Creative and cultural industries}

$\rightarrow \quad$ Creative and cultural industries encompass a broader range of activities that include creative and cultural production. In an Arctic context, it often emphasises human creativity as a way to leverage cultural heritage and translate it into a business. ${ }^{40}$

\section{Research Approach}

To achieve the aim of this study, a three-phase research approach was developed as illustrated below.

\begin{tabular}{|c|c|c|}
\hline $\begin{array}{l}\text { Mapping \& } \\
\text { Cross-Analysis }\end{array}$ & Case Studies & $\begin{array}{l}\text { Findings \& } \\
\text { Recommendations }\end{array}$ \\
\hline $\begin{aligned} \rightarrow & \text { Mapping key policies } \\
\rightarrow & \text { Mapping recent economic } \\
& \text { activity } \\
\rightarrow & \text { Cross-analysis of focal areas } \\
\rightarrow & \text { Identification of drivers and } \\
& \text { enablers }\end{aligned}$ & $\begin{aligned} \rightarrow & \text { Case study selection } \\
\rightarrow & \text { Development of case studies } \\
\rightarrow & \text { Identification of drivers and } \\
& \text { enablers }\end{aligned}$ & $\begin{aligned} \rightarrow & \text { Stakeholder review of findings } \\
& \text { an hypotheses } \\
\rightarrow & \text { Development of recommen- } \\
& \text { dations }\end{aligned}$ \\
\hline
\end{tabular}




\section{Mapping \& Cross-Analysis}

The mapping sought to identify policies and recent economic activity within the focal areas through extensive desk research. The key insights from the mapping were consolidated in a cross-analysis framework that assessed and correlated the level of policy support with the level of economic activity. The combination of factors indicated opportunities concerning policy and economic activity and gaps for sectors in each focal area. This generated hypotheses on enabling and constraining factors, as well as developed an overview of business development potential in the Nordic Arctic. Considering the challenge in quantifying and measuring the topics of this study, a score-based method was developed based on a qualitative assessment of the policies promoting economic activity and available data on actual economic activity in the Nordic Arctic. The multiple scoring method relied on a pre-defined assessment scale and estimations from various project collaborators.

\section{Case Studies}

Enabling and constraining factors identified in the cross-analysis were further examined through case studies of selected businesses, organisations, and projects identified during the desk research and the cross-analysis. Case studies were selected based on their ability to enrich the analysis of gaps and enablers, and ability to scale potential learnings to other businesses, industries, and potentially other Arctic areas.

\section{Findings \& Recommendations}

Findings and hypotheses from the mapping, cross-analysis, and case studies were assessed and reviewed by several stakeholders in the Nordic Arctic region for evaluation, further development, and final assessment. Finally, knowledge and conclusions were synthesised to develop recommendations on ways in which the Nordic Co-operation, specifically Nordic Council of Ministers (NCM), and other Arctic actors can support specific initiatives in the future to facilitate economic growth, investment, and business development in the Nordic Arctic region. 
Amundsen, Helene. "Differing Discourses of Development in the Arctic: The Case of Nature-Based Tourism in Northern Norway." The Northern Review, 2012.

Central Intelligence Agency. "The World Factbook," 2017. https:// www.cia.gov/library/publications/ the-world-factbook/geos/gl.html.

Dáiddadállu. "Om Oss," n.d. http:// www.daiddadallu.com/om-oss/.

FAROEISLANDS.FO. "Tourism," 2017. http://www.faroeislands.fo/economy-business/tourism/.

Film in Iceland. "Film In Iceland," n.d. http://www.filminiceland.com/ about/.

Gardiner, Ann, Matthieu Bardout, Francesca Grossi, and Sandrine Dixson-Declève. "Public-Private Partnerships for Climate Finance," 2016. https://doi.org/10.6027/ TN2015-577.

Genc, Ruhet. "Turning Weaknesses Into Strengths: Nordic Tourism, Potentials for Growth and Major Challanges." Acta Iniversitatis Danubius, 2010.

Hautala-Hirvioja, Tuija. "Reflections of the Past: A Meeting between Sámi Cultural Heritage and Contemporary Finnish Sámi." In Relate North - Art, Heritage \& Identity, edited by Timo Jokela and Glen Coutts. Lapland University Press, 2015.

Icelandic Tourist Board. "Tourism Administration Act," 2005. https:// www.ferdamalastofa.is/en/licences-legislation/tourism-administration-act.

Innovation Norway. "Key Figures for Norwegian Travel and Tourism 2015," 2015.

Islandsbanki. "Tourism in Iceland," 2016.

Jonsson, Grimar, Emile Hertling Peronard, and Mikkjal Niels Helmsdal. "North Atlantic Talents," 2016.
Ministry of Fisheries, Hunting and Agriculture. "Management and Utilization of Seals in Greenland," 2012.

Njos, R., S.-E. Jakobsen, H. Wiig Aslesen, and A. Floysand. "Encounters between Cluster Theory, Policy and Practice in Norway: Hubbing, Blending and Conceptual Stretching." European Urban and Regional Studies, 2016. http://eur.sagepub.com/cgi/ doi/10.1177/0969776416655860.

Nordic Council of Ministers. "25 Cases for Sustainable Change," 2017. https://doi.org/10.6027/ANP2016782.

---. A Good Life in a Sustainable Nordic Region. Nordic Strategy for Sustainable Development, 2013. https://doi.org/10.6027/ANP2013728.

Norwegian Film Institute. "Facts and Figures 2014," 2014.

OECD. "Finland." In OECD Tourism Trends and Policies 2016. Paris: OECD Publishing, 2016. . "Iceland." In OECD Tourism Trends and Policies 2016. Paris: OECD Publishing, 2016.

Olsen, Lise Smed, Anna Berlina, Leneisja Jungsberg, Nelli Mikkola, Johanna Roto, Rasmus Ole Rasmussen, and Anna Karlsdottir. "Sustainable Business Development in the Nordic Arctic," 2016.

"Promote Iceland," 2017. http://www. islandsstofa.is/en/about/.

Reffstrup, T., and S.K. Christensen. "Nordic Entrepreneurship Islands," 2017.

Ren, Carina, and Daniela Chimirri. "TURISMEUDVIKLING I GRØNLAND - AFDAENING OG INSPIRATION," 2017.

Sametinget. "Analysis of Sapmi," 2014.

Statistics Greenland. "Greenland in Figures," 2017.

Statistics Iceland. "Enterprises and Operational Information 20122014: 59 - Motion Picture, Video and Television Programme Production, Sound Recording and Music
Publishing Activities," 2015. http:// px.hagstofa.is/pxen/pxweb/en/Atvinnuvegir/Atvinnuvegir_fyrirtaeki_afkoma_1_afkoma/FYR08000. $\mathrm{px} /$ ?rxid=27dfeeeO-f898-4df1b220-26d63007a376.

Stępień, Adam, and Timo Koivurova. "Arctic Europe: Bringing Together the EU Arctic Policy and Nordic Cooperation." Government's Analysis, Assessment and Research Activities, no. 15 (2017). http://tietokayttoon. fi/documents/10616/3866814/15 Arctic+Europe_Bringing+together+the+EU+Arctic+Policy. pdf/761dc7e8-ad2d-4d9a-a2f2f0436 efd5063? version=1.0.

Sweden.se. "Sami in Sweden," 2017.

Swedish Agency for Economic and Regional Growth. "Tourism in Sweden," 2015.

UNESCO. "Understanding Creative Industries. Cultural Statisitcs for Public Policy-Making." Global Alliance Team, 2006, 8. http://portal. unesco.org/culture/en/ev.php-URL_ ID =29947\&URL_DO=DO_TOPIC\&URL_SECTION=-465.html.

Vintertroms. "About "Winter Experiences Northern Norway"," n.d. http://www.vintertroms.no/ english/.

Visit Faroe Islands. "Visit Faroe Islands Annual Report 2016," 2016.

Visit Greenland. "Tourism Statistics Report 2016," 2016. http://tourismstat.gl/resources/reports/en/ r8/GREENLAND TOURISM REPORT 2016.pdf. 
1 Nordic Council of Ministers, A Good Life in a Sustainable Nordic Region. Nordic Strategy for Sustainable Development, 2013. https://doi. org/10.6027/ANP2013-728.

2 Lise Smed Olsen et al., "Sustainable Business Development in the Nordic Arctic," 2016.

3 Grimar Jonsson, Emile Hertling Peronard, and Mikkjal Niels Helmsdal, "North Atlantic Talents," 2016.

4 Statistics Iceland, "Enterprises and Operational Information 20122014: 59 - Motion Picture, Video and Television Programme Production, Sound Recording and Music Publishing Activities," 2015, http:// px.hagstofa.is/pxen/pxweb/en/Atvinnuvegir/Atvinnuvegir_fyrirtaeki_afkoma_1_afkoma/FYR08000. $\mathrm{px} /$ ?rxid=27dfeee0-f898-4df1b220-26d63007a376.

5 Norwegian Film Institute, "Facts and Figures 2014," 2014.

6 Jonsson, Peronard, and Helmsdal, "North Atlantic Talents."

7 Ibid.

8 Islandsbanki, "Tourism in Iceland," 2016.

9 Icelandic Tourist Board, "Tourism Administration Act," 2005, https:// www.ferdamalastofa.is/en/licences-legislation/tourism-administration-act.

10 Innovation Norway, "Key Figures for Norwegian Travel and Tourism 2015," 2015.

11 OECD, "Finland," in OECD Tourism Trends and Policies 2016 (Paris: OECD Publishing, 2016).

12 Swedish Agency for Economic and Regional Growth, "Tourism in Sweden," 2015.

13 OECD, "Iceland," in OECD Tourism Trends and Policies 2016 (Paris: OECD Publishing, 2016).

14 FAROEISLANDS.FO, "Tourism," 2017, http://www.faroeislands.fo/ economy-business/tourism/.

15 Visit Faroe Islands, "Visit Faroe Islands Annual Report 2016," 2016.
16 Visit Greenland, "Tourism Statistics Report 2016," 2016, http:// tourismstat.gl/resources/reports/ en/r8/GREENLAND TOURISM REPORT 2016.pdf.

17 Carina Ren and Daniela Chimirri, "TURISMEUDVIKLING I GRØNLAND - AFDAEKNING OG INSPIRATION," 2017.

18 Sweden.se, "Sami in Sweden," 2017.

19 Central Intelligence Agency, "The World Factbook," 2017, https:// www.cia.gov/library/publications/ the-world-factbook/geos/gl.html.

20 Sametinget, "Analysis of Sapmi," 2014.

21 Dáiddadállu, "Om Oss," n.d., http:// www.daiddadallu.com/om-oss/.

22 Tuija Hautala-Hirvioja, "Reflections of the Past: A Meeting between Sámi Cultural Heritage and Contemporary Finnish Sámi," in Relate North - Art, Heritage \& Identity, ed. Timo Jokela and Glen Coutts (Lapland University Press, 2015).

23 Hunting and Agriculture Ministry of Fisheries, "Management and Utilization of Seals in Greenland," 2012.

24 Jonsson, Peronard, and Helmsdal, "North Atlantic Talents."

25 Statistics Greenland, "Greenland in Figures," 2017.

26 Film in Iceland, "Film In Iceland," n.d., http://www.filminiceland.com/ about/.

27 "Promote Iceland," 2017, http:// www.islandsstofa.is/en/about/.

28 Helene Amundsen, "Differing Discourses of Development in the Arctic: The Case of Nature-Based Tourism in Northern Norway," The Northern Review, 2012.

29 Vintertroms, "About "Winter Experiences Northern Norway"," n.d., http://www.vintertroms.no/english/.

30 OECD, "Iceland."

31 Amundsen, "Differing Discourses of Development in the Arctic: The Case of Nature-Based Tourism in Northern Norway."
32 Olsen et al., "Sustainable Business Development in the Nordic Arctic"; Ruhet Genc, "Turning Weaknesses Into Strengths: Nordic Tourism, Potentials for Growth and Major Challanges," Acta Iniversitatis Danubius, 2010.

33 Adam Stępień and Timo Koivurova, "Arctic Europe: Bringing Together the EU Arctic Policy and Nordic Cooperation," Government's Analysis, Assessment and Research Activities, no. 15 (2017), http://tietokayttoon. fi/documents/10616/3866814/15_ Arctic+Europe_Bringing+together+the+EU+Arctic+Policy. pdf/761dc7e8-ad2d-4d9a-a2f2f0436 efd5063? version $=1.0$.

34 https://www.lapland.fi/arctic-biz/ data-numbers/.

35 Incentives and opportunities related to Denmark will be mentioned in they specifically relate to Greenland or the Faroe Islands.

36 T. Reffstrup and S.K. Christensen, "Nordic Entrepreneurship Islands," 2017.

37 Ann Gardiner et al., "Public-Private Partnerships for Climate Finance," 2016, https://doi.org/10.6027/ TN2015-577.

38 R. Njos et al., "Encounters between Cluster Theory, Policy and Practice in Norway: Hubbing, Blending and Conceptual Stretching," European Urban and Regional Studies, 2016, http://eur.sagepub.com/cgi/ doi/10.1177/0969776416655860.

39 Nordic Council of Ministers, "25 Cases for Sustainable Change."

40 UNESCO, "Understanding Creative Industries. Cultural Statisitcs for Public Policy-Making," Global Alliance Team, 2006, 8, http://portal. unesco.org/culture/en/ev.php-URL_ $I D=29947 \& U R L \_D O=D O \_T O P-$ IC\&URL_SECTION=-465.html. 


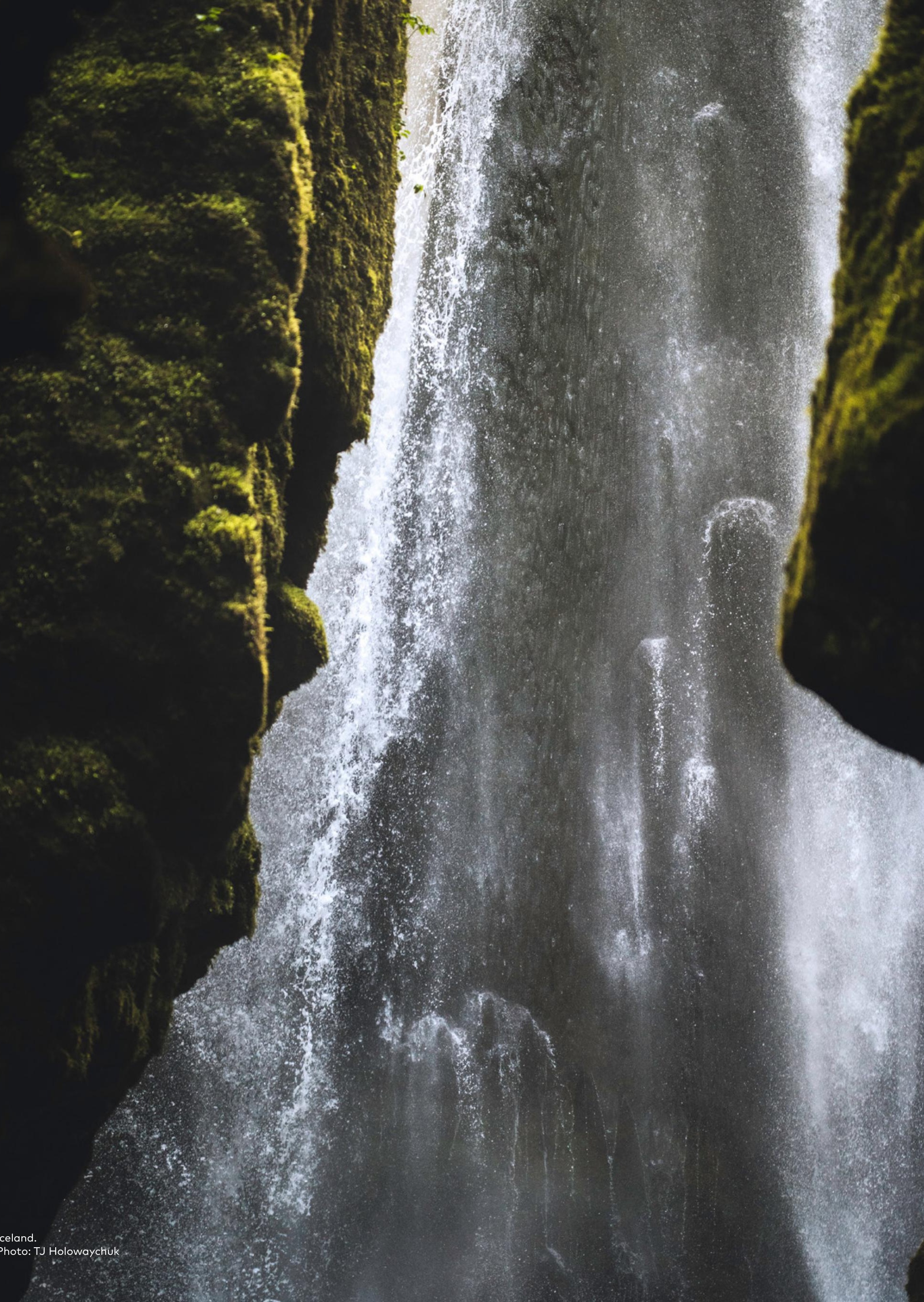


D(1) AEC Voluntās 


\section{Arctic Business Analysis}

- Opportunities for people, businesses and investments

In 2016, the Nordic Cooperation Ministers decided to put more emphasis on economic development in the Arctic within the Arctic Cooperation Program of the Nordic Council of Ministers.

The Nordic Council of Ministers partnered up with the Arctic Economic Council in carrying out an Arctic Business Analysis. The aim was to qualify knowledge on the business environment in the Nordic Arctic and how to take the business environment to a next level.

The analysis covers 1) Entrepreneurship and Innovations; 2) PublicPrivate Partnerships \& Business Cooperation; 3) Bio-economy, and 4) Creative and Cultural Industries.

The general findings of the analysis are:

$\rightarrow \quad$ a need for an increased collection and dissemination of Arctic specific data;

$\rightarrow \quad$ a need for strengthened cross-border business collaboration between regions and actors in the Arctic; and

$\rightarrow \quad$ a need for a positive branding of the Arctic as an attractive and sustainable market for investments and economic development. 